\title{
Microplastics in Aquatic Systems - Monitoring Methods and Biological Consequences
}

\author{
Thea Hamm, Claudia Lorenz, and Sarah Piehl
}

\begin{abstract}
Microplastic research started at the turn of the millennium and is of growing interest, as microplastics have the potential to affect a whole range of organisms, from the base of the food web to top predators, including humans. To date, most studies are initial assessments of microplastic abundances for a certain area, thereby generally distinguishing three different sampling matrices: water, sediment and biota samples. Those descriptive studies are important to get a first impression of the extent of the problem, but for a proper risk assessment of ecosystems and their inhabitants, analytical studies of microplastic fluxes, sources, sinks, and transportation pathways are of utmost importance. Moreover, to gain insight into the effects microplastics might have on biota, it is crucial to identify realistic environmental concentrations of microplastics. Thus, profound knowledge about the effects of microplastics on biota is still scarce. Effects can vary regarding habitat, functional group of the organism, and polymer type for example, making it difficult to find quick answers to the many open questions. In addition, microplastic research is accompanied by many methodological challenges that need to be overcome first to assess the impact of microplastics on aquatic systems. Thereby, a development of standardized operational protocols (SOPs) is a pre-requisite for comparability among studies. Since SOPs are still lacking and new methods are
\end{abstract}

\section{T. Hamm}

GEOMAR Helmholtz Center for Ocean Research, Kiel, Germany

e-mail: thamm@geomar.de

C. Lorenz $(\bowtie)$

Alfred Wegener Institute (AWI), Helmholtz Centre for Polar and

Marine Research, Biologische Anstalt Helgoland,

Helgoland, Germany

e-mail: claudia.lorenz@awi.de

S. Piehl

Department of Animal Ecology I and BayCEER, University of

Bayreuth, Bayreuth, Germany

e-mail: sarah.piehl@uni-bayreuth.de developed or optimized very frequently, the aim of this chapter is to point out the most crucial challenges in microplastic research and to gather the most recent promising methods used to quantify environmental concentrations of microplastics and effect studies.

\section{Introduction}

Literature on microplastic (MP) abundance in aquatic environments and observed effects on biota has exponentially increased over the last 7 years (Connors et al. 2017). Within the current literature, MP sampling is imbalanced and studies are most often conducted on sandy beaches and the sea surface, followed by bottom sediment samples and water column samples (Duis and Coors 2016; Bergmann et al. 2017). Individual studies examining MP abundance, i.e., deep sea sediments (Van Cauwenberghe et al. 2013b; Woodall et al. 2014), sea ice (Obbard et al. 2014) or marine snow (Zhao et al. 2017) exist. Thereby, attempts to compare data taken from similar sampling matrices have been made in almost every study (Filella 2015), whereas for most studies this is often hampered by the various sampling methods applied (Hidalgo-Ruz et al. 2012; Filella 2015; Löder and Gerdts 2015; Costa and Duarte 2017). Hidalgo-Ruz et al. (2012) was the first article that showed the huge variety of different methods used for MP data collection and suggested the need for standardized operational protocols (SOPs). In the "Guidelines for Monitoring of marine litter" published by Hanke et al. (2013) the authors suggested methods based on the most often used techniques but also stressed that further standardization is needed. The NOAA made initial attempts of standardization in laboratory methods (Masura et al. 2015). Moreover, Löder and Gerdts (2015), as well as more recently Costa and Duarte (2017), took up the issue and critically assessed the different methods used for MP analysis. However, different environments can only be compared 
to a certain extent, as the different sample matrices require different sampling methods. Moreover, as replication of samples is limited within a project, the high spatial and temporal variability of MPs in the various environments poses another major challenge in MP research (Goldstein et al. 2013; Moreira et al. 2016; Imhof et al. 2017). Whereas some recommendations for spatial replication have been made, no general consensus exists about temporal replication (Hanke et al. 2013). As a next step, the impact of the determined environmental concentrations of MP on biota is interesting. Parallel to monitoring studies, the toxicological implications for biota have been addressed in many studies. So far, we know that MPs are ingested by a wide range of organisms from the base of the food web up to top predators. As the environmental concentrations have not yet been sufficiently analyzed, exposure to MPs in laboratory studies are applying high concentrations to get first insights into possible effects following ingestion. This chapter aims to summarize the main results of the latest 3 years of research on sampling and monitoring methods as well as to give an overview about observed effects of MP exposure on biota.

\section{Sampling Design}

Previous research already addressed the problem of an appropriate sampling design (Browne et al. 2015; Löder and Gerdts 2015; Costa and Duarte 2017). A detailed review on the topic is given by Underwood et al. (2017). Over the last years, some studies focused on improving sampling design (Chae et al. 2015; Kang et al. 2015; Barrows et al. 2017) and aimed to investigate spatial and temporal patterns of MPs (Goldstein et al. 2013; Heo et al. 2013; Besley et al. 2017; Fisner et al. 2017; Imhof et al. 2017). Moreover, a few recommendations and protocols for sampling exist (Hanke et al. 2013; GESAMP 2016; Kovač Viršek et al. 2016). Potential factors which need to be considered when sampling beach sediments are summarized in Fig. 1. Some of the main issues are discussed in the following for both, water and sediment samples.

In each study, scientists should first determine the appropriate study area suitable for their research question. Thereby, factors such as, for example, proximity to potential sources (i.e., cities, harbors, industry), ocean currents and sampled sediment type need to be considered, as they can influence composition of MPs as well as the abundances (Hanvey et al. 2017). As a next step, a sampling design needs to be chosen, which suits the study question and is representative of the study area. Although most studies are initial assessments of MP concentrations, most often potential accumulation sites have been sampled (e.g., high tide line on beaches or ocean surface) (Filella 2015; Bergmann et al. 2017; Hanvey et al. 2017). Therefore, results cannot be extrapolated to the whole study area, as this kind of sampling is designed to find MP contamination. If the objective of the study is to assess the contamination level of the whole area, the sampling design could be improved by expanding the sampling to spots, which are not expected to have high amounts of MPs. Thus, random

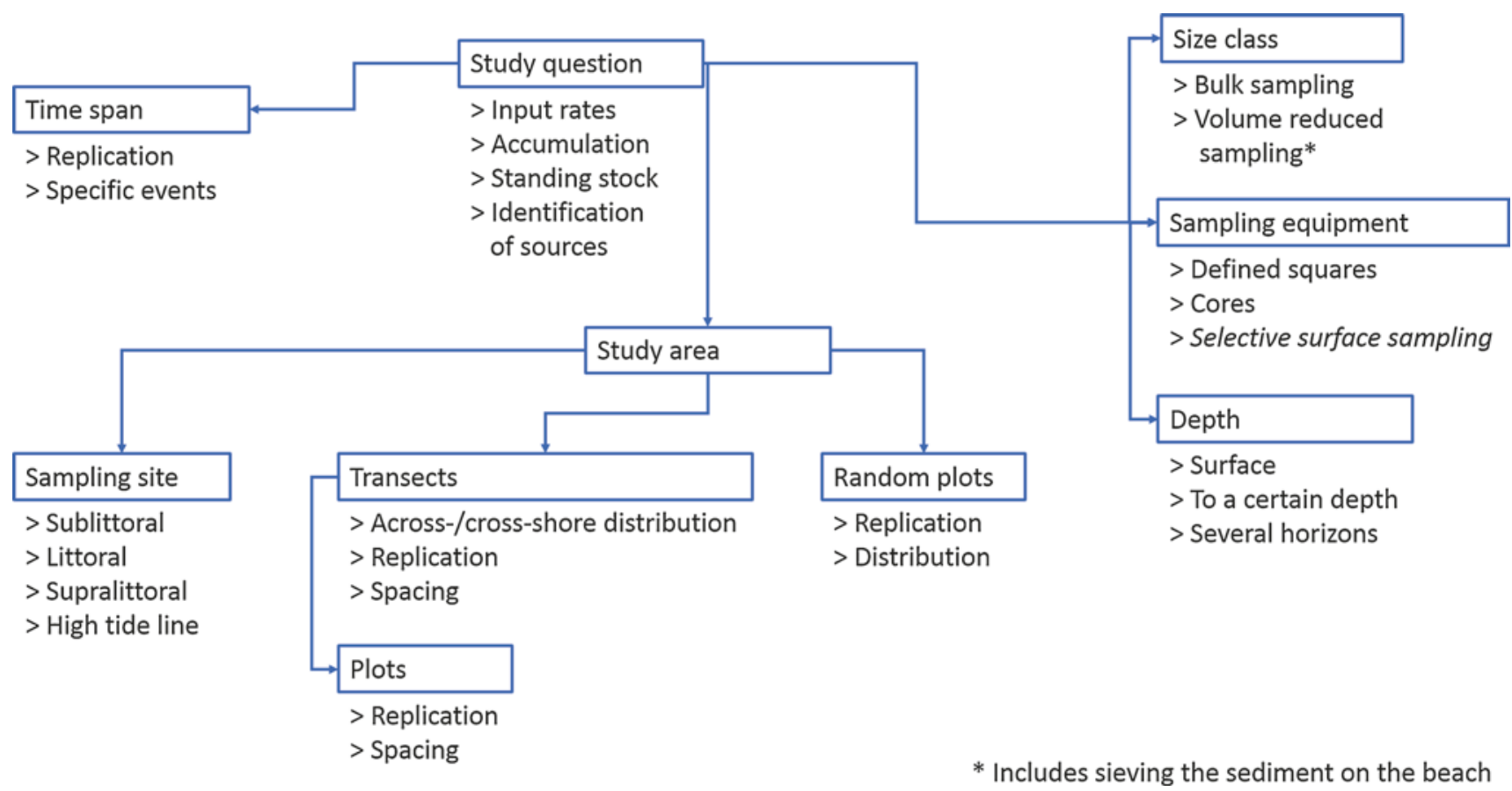

Fig. 1 Overview of factors, which need to be considered when planning a microplastics sampling campaign, exemplary for beach sediment samples 
sampling, e.g., of a section of a beach, including the whole vertical and horizontal dimension, could be an option, although not yet conducted for MPs. In any case, care should be taken when formulating research questions, as this will set the framework for considerations regarding the sampling design.

\section{Spatial and Temporal Replication}

To get a representative sample, care needs to be taken with respect to appropriate replication as well as the amount of sample, which will be taken. If study areas of various sizes are compared, it needs to be considered, whether the number of replicates is kept the same or whether they are adjusted to the area (balanced vs. unbalanced sampling design). For beach sediment, Kim et al. (2015) adjusted sampling effort to beach size, whereas the majority of studies kept replicate numbers the same. In the current literature, replicate samples for one beach can range from one to 88 (Besley et al. 2017), whereas recommendations suggest a replication of at least five (Hanke et al. 2013). For beach sediments, Dekiff et al. (2014) found no significant variability in MP abundance within a $100 \mathrm{~m}$ transect, taking six replicate samples. Low spatial variability on a small scale (within tens of $\mathrm{m}$ ) was further found in a recent study from Fisner et al. (2017) on plastic pellets ( 1-6 mm; (Hidalgo-Ruz et al. 2012), whereas this study further found a high spatial variability on a large scale (within km). Contrary, Besley et al. (2017), including smaller MPs (300-5000 $\mu \mathrm{m})$, found a high spatial variability among ten samples on a transect of $100 \mathrm{~m}$. Confidence intervals around the mean in this study decreased rapidly after a replication of five, and 11 replicates would be needed to reach a 0.5 standard deviation at a confidence level of $90 \%$ (Besley et al. 2017). Those results are supported by a further study concentrating on large MPs (1-5 mm) on a $100 \mathrm{~m}$ transect on a tropical beach (six replicates; (Imhof et al. 2017). For surface water samples there is one study investigating spatial variability within the eastern North Pacific, off California $\left(\sim 20^{\circ}-40^{\circ} \mathrm{N}, 120^{\circ}-155^{\circ} \mathrm{W}\right.$; (Goldstein et al. 2013). They found that MP concentrations were highly variable over relatively small scales (tens of $\mathrm{km}$ ) as well as for large scales (hundreds to thousands of $\mathrm{km}$ ).

It is also stated that MP abundance varies over numerous temporal scales and detection of temporal trends are often hampered by the sampling design (Browne et al. 2015). Recent studies conducted on beaches found high daily variability due to tidal dynamics (Moreira et al. 2016; Imhof et al. 2017). One possibility to improve knowledge about temporal patterns could be through ice or sediment cores (Costa and Duarte 2017), by analyzing different layers separately. For the water surface, high inter-annual variability was found (Law et al. 2010; Doyle et al. 2011; Law et al. 2014), whereas Law et al. (2010), investigating a 22-year dataset of surface plankton net tows, found no strong temporal trends in MP concentrations within this data set. Nevertheless, the time span needed for a sampling campaign should be considered beforehand. For example for beach sediment sampling, sampling periods range over several hours to years (Browne et al. 2015). Whereas for some study questions, sampling over a certain period of time may not be a problem, for others it could lead to biased results. This might, for instance, apply to the sampling of various river mouths at a delta over several days. Strongly changing precipitation between sampling days could hamper comparability, as MP runoff could be enhanced during days of heavy rainfall, similar to what was hypothesized in a recent study comparing MP load of waste water treatment plants effluents on two different dates with differing participation events (Primpke et al. 2017a).

\section{Sampling Depth}

For both, sediments and water column, the optimal sampling depth remains another open question. Sediment sampling is recommended to a depth of at least $5 \mathrm{~cm}$ (Hanke et al. 2013; Besley et al. 2017), whereas studies report that a potential proportion can be lost if deeper sediment layers are not sampled (Carson et al. 2011; Claessens et al. 2011). Thus, it has already been stated that samples should be taken at a depth to $1 \mathrm{~m}$, to get a more precise picture of MP abundances (Turra et al. 2014; Fisner et al. 2017). For the water column, only few studies exist where different depths were concurrently sampled (Lattin et al. 2004; Reisser et al. 2015). In one study, no significant differences were found between the sea surface, the water column ( $5 \mathrm{~m}$ depth), and above the bottom (Lattin et al. 2004), whereas the other found that MP concentrations decreased exponentially, with highest amounts within the first $0.5 \mathrm{~m}$ of the water column (Reisser et al. (2015). This is confirmed by Goldstein et al. (2013), detecting the highest concentrations of MPs during low wind conditions, when minimal mixing occurs between shallow and deeper water layers. The optimal sampling depth will finally be a compromise between increasing sampling surface and sampling depth and thus will also be determined by the research question.

\section{Reporting of Data}

Though different methods are necessary depending on the research question, researchers should aim for standardization, the most important one being size classes and reporting units. Regarding size classes the upper limit for MPs is $5 \mathrm{~mm}$, whereas the lower limit will be defined by the sampling device, as well as the analytical method. Initial 
studies investigating size distribution found generally increasing abundances with decreasing size classes (Imhof et al. 2016). Even though the applied methodology will define the lower size limit, the post-sampling procedures will allow for classification into different size classes. Thereby, Hanke et al. (2013) recommended to allocate MP particles into size bins of $100 \mu \mathrm{m}$. Although this recommendation would provide high resolution datasets, in practice this is almost not feasible, as the preparation of microplastic samples is already very time consuming and, for instance, additional sieving steps would further increase analysis time. Further, depending on the research question different size categories are of importance. If, for example, pictures of the microplastic particles are taken during analysis, it is possible to obtain data on the size at a later time point in case the data would be requested for comparative analysis.

Standardization of reporting units is a further necessity to increase comparability among data sets. So far, different sampling strategies have led to various reporting units (e.g., $\mathrm{m}^{2}, \mathrm{~m}^{3}, \mathrm{ml}, \mathrm{l}, \mathrm{g}, \mathrm{kg}$ ) (Hidalgo-Ruz et al. 2012; Löder and Gerdts 2015; Costa and Duarte 2017). For MPs in the environment (excluding biota samples) either bulk or volume reduced samples are taken. Thus, a volume measurement can always be obtained and should be the minimum information reported. Additional reporting of sampling depth as well as weight measurements for sediment samples will further increase data quality.

Finally, reporting of meta data like prevailing wind direction, sea state, beach morphology, rainfall, and so on would improve the interpretation of the data collected (Barrows et al. 2017). In the current literature, missing information range from unreported size ranges, replication, detected numbers of particles to sampling locations (Filella 2015; Besley et al. 2017). Comprehensive reporting of the applied methods is a crucial part and not only a requirement for reproducibility, but further gives the reader the ability to judge about the representativeness of the study, as well as the conclusions drawn from the results.

\section{Sampling Equipment}

Further considerations should be made on the sampling equipment, as this will define the size range of MPs in the study, as well as reporting units. For beach sediments, sampling equipment is well established (Hidalgo-Ruz et al. 2012; Hanvey et al. 2017), it only remains important to consider, whether to collect a bulk or a volume reduced sample. For the latter, a lower size limit is defined. For bottom sediments corers, Van Veen or Ekman grabs can be used, however, grabs disturb the surface layer of the sediment and corers do not only take the sediment but also the water layer above the sediment (Löder and Gerdts 2015).

For water samples, nets of various types have been used (Table 1 gives an overview of the used equipment found in the current literature). Most commonly, manta nets are the device of choice (Costa and Duarte 2017), where the reduced sample volume limits the lowest size class of investigated MPs mostly to 300-350 $\mu \mathrm{m}$ (Filella 2015). Thus, some researchers used bottles to take bulk samples of the water surface (Dubaish and Liebezeit 2013; Barrows et al. 2017), which, however, results in small sample volumes. Nevertheless, sampling lower size ranges, Barrows et al. (2017) found MP concentrations were several orders of magnitude higher in bottle samples than manta samples. To obtain larger sample volumes, others took several bottles or buckets of surface water and concentrated the material on filters with smaller mesh sizes on board (hand-nets; Chae et al. 2015; Kang et al. 2015). Moreover, contamination issues through high air exposure times during a manta trawl, as well as filtering samples on board, motivated researchers to further develop pumping systems (Desforges et al. 2014; Lusher et al. 2014; Enders et al. 2015). One of the first studies comparing different methodologies for the same size class (300-5000 $\mu \mathrm{m})$ was conducted by Setälä et al. (2016) comparing their custom-made pump to manta trawls. Preliminary results from the pump (collecting surface water in a depth of $0-0.5 \mathrm{~m}$ ) did not significantly differ from the results obtained by the manta net. Another interesting solution to decrease sampling effort has been published by Edson and Patterson (2015). They designed an automated sampling device (MantaRay), which automatically pumps sea surface water at a depth of $30 \mathrm{~cm}$, while drifting through the water. Thereby, particles are concentrated on a filter and 28 successive samples can be taken. For the prototype, $500 \mu \mathrm{m}$ stainless steel sieves were used. Such an instrument can decrease sampling effort and airborne contamination, which is often a challenge when conducting trawls. One drawback could be the autonomous operation of the MantaRay, which limits the control over the area sampled. Moreover, an optical sensor is implemented to ensure that only water containing particulate matter is filtered. Thereby, especially small MP particles could be overlooked so the influence on the obtained results must be further evaluated.

Independent of the applied method, decreasing mesh sizes will increase the content of organic and inorganic material, which could lead to smaller sample sizes as meshes will become clogged faster, but also to increased sample preparation time in the laboratory. In any case, negative controls should be run, as most of the used methods may contain polymer materials which are a further source for contamination. 
Table 1 Comparison of various methods used to collect water samples for the analysis of microplastics (MP) in different compartments. Pro and contra are always relative with regard to the sampling devices used for the specific compartment

\begin{tabular}{|c|c|c|c|c|c|}
\hline $\begin{array}{l}\text { Sampled } \\
\text { compartment }\end{array}$ & $\begin{array}{l}\text { Most common } \\
\text { used equipment }\end{array}$ & General description & Pro & Contra & References \\
\hline \multirow[t]{2}{*}{$\begin{array}{l}\text { Sea surface } \\
\text { microlayer } \\
(\mathrm{SML})\end{array}$} & $\begin{array}{l}\text { Rotating drum } \\
\text { sampler }\end{array}$ & $\begin{array}{l}\text { Drum is towed over the water } \\
\text { surface and SML is sampled } \\
\text { under capillary force by the } \\
\text { rotating drum and collected in } \\
\text { glass containers }\end{array}$ & $\begin{array}{l}\text { reduced contamination } \\
\text { issues } \\
\text { large sample volume }\end{array}$ & $\begin{array}{l}\text { only a small part of } \\
\text { SML is sampled ( } 50-60 \\
\mu \mathrm{m})^{*} \\
\text { water adhering to the } \\
\text { drum may dilute the } \\
\text { sample } \\
\text { device materials need to } \\
\text { be considered }\end{array}$ & $\begin{array}{l}\text { Ng and Obbard } \\
(2006)\end{array}$ \\
\hline & Screen sampler & $\begin{array}{l}\text { Water surface is gently } \\
\text { touched with a metal sieve } \\
\text { with specific pore size; MP } \\
\text { particles and SML water is } \\
\text { trapped within the metal sieve } \\
\text { mesh by surface tension }\end{array}$ & $\begin{array}{l}\text { easy handling and } \\
\text { transport } \\
\text { larger part of SML is } \\
\text { covered compared to } \\
\text { rotating drum sampler }\end{array}$ & $\begin{array}{l}\text { only a part of SML is } \\
\text { sampled }(150-400 \mu \mathrm{m})^{*} \\
\text { variation can be caused } \\
\text { by different operators } \\
\text { contamination through } \\
\text { higher air exposure times }\end{array}$ & Song et al. (2014) \\
\hline \multirow[t]{4}{*}{ Water surface } & $\begin{array}{l}\text { Manta or } \\
\text { plankton/ } \\
\text { neuston nets } \\
\text { with flowmeter }\end{array}$ & $\begin{array}{l}\text { Net is towed over the water } \\
\text { surface to a certain depth } \\
\text { (depending on mouth opening) } \\
\text { and volume recorded with a } \\
\text { flowmeter }\end{array}$ & $\begin{array}{l}\text { large sample sizes } \\
\text { exact for the water } \\
\text { surface layer } \\
\text { integrates a high area of } \\
\text { sea surface }\end{array}$ & $\begin{array}{l}\text { investigated size class } \\
\text { limited (mesh size often } \\
\sim 300 \mu \mathrm{m}) \\
\text { contamination through } \\
\text { higher air exposure } \\
\text { times and material of } \\
\text { equipment } \\
\text { plankton/neuston nets: } \\
\text { opening obstructed by } \\
\text { ropes for towing }\end{array}$ & $\begin{array}{l}\text { Barrows et al. } \\
\text { (2017) and Costa } \\
\text { and Duarte (2017) }\end{array}$ \\
\hline & $\begin{array}{l}\text { Bulk sampling } \\
\text { with bottles }\end{array}$ & $\begin{array}{l}\text { Water samples are taken } \\
\text { directly from water surface } \\
\text { and bottles closed below } \\
\text { surface to reduce } \\
\text { contamination }\end{array}$ & $\begin{array}{l}\text { whole size range of MPs } \\
\text { can be sampled } \\
\text { reduced contamination } \\
\text { issues }\end{array}$ & $\begin{array}{l}\text { small sample sizes may } \\
\text { result in a high } \\
\text { variability } \\
\text { varying sampling depth }\end{array}$ & $\begin{array}{l}\text { Dubaish and } \\
\text { Liebezeit (2013) } \\
\text { and Barrows et al. } \\
\text { (2017) }\end{array}$ \\
\hline & $\begin{array}{l}\text { Bulk sampling } \\
\text { with hand-net }\end{array}$ & $\begin{array}{l}\text { Water sample is taken with a } \\
\text { container and poured over } \\
\text { stainless steel meshes on board }\end{array}$ & $\begin{array}{l}\text { whole size range of MPs } \\
\text { can be sampled } \\
\text { pre-separation of size } \\
\text { classes possible } \\
\text { large sample sizes can } \\
\text { be obtained }\end{array}$ & $\begin{array}{l}\text { varying sampling depth } \\
\text { contamination through } \\
\text { higher air exposure } \\
\text { times } \\
\text { device materials need to } \\
\text { be considered }\end{array}$ & $\begin{array}{l}\text { Chae et al. (2015) } \\
\text { and Kang et al. } \\
(2015)\end{array}$ \\
\hline & $\begin{array}{l}\text { Pumping } \\
\text { systems }\end{array}$ & $\begin{array}{l}\text { Seawater is either collected via } \\
\text { the intake of a ship, a hose or a } \\
\text { submersible pump }\end{array}$ & $\begin{array}{l}\text { whole size range of MPs } \\
\text { can be sampledpre- } \\
\text { separation of size } \\
\text { classes possible } \\
\text { large sample sizes can } \\
\text { be obtained } \\
\text { reduced contamination } \\
\text { issues }\end{array}$ & $\begin{array}{l}\text { varying sampling depth } \\
\text { smaller mesh sizes lead } \\
\text { to faster blocking of the } \\
\text { filters } \\
\text { device materials need to } \\
\text { be considered }\end{array}$ & $\begin{array}{l}\text { Desforges et al. } \\
\text { (2014), Enders } \\
\text { et al. (2015), } \\
\text { Lusher et al. } \\
\text { (2014) and Setälä } \\
\text { et al. (2016) }\end{array}$ \\
\hline \multirow[t]{3}{*}{$\begin{array}{l}\text { Water } \\
\text { column }\end{array}$} & Bongo nets & $\begin{array}{l}\text { Paired zooplankton nets joined } \\
\text { by a central axle }\end{array}$ & $\begin{array}{l}\text { large sample sizes } \\
\text { integrates a high area of } \\
\text { water column } \\
\text { unobstructed by towing } \\
\text { ropes }\end{array}$ & $\begin{array}{l}\text { investigated size class is } \\
\text { limited through mesh } \\
\text { size } \\
\text { contamination through } \\
\text { material of equipment }\end{array}$ & Lattin et al. (2004) \\
\hline & $\begin{array}{l}\text { Continuous } \\
\text { plankton } \\
\text { recorder }(\mathrm{CPR})\end{array}$ & $\begin{array}{l}\text { A box for filtering particles at } \\
\text { a depth between } 5-10 \mathrm{~m} \text {; } \\
\text { material is concentrated on } \\
\text { continuously moving bands of } \\
\text { filter silk }\end{array}$ & $\begin{array}{l}\text { low operation effort } \\
\text { archived data records } \\
\text { available }\end{array}$ & $\begin{array}{l}\text { smaller MP particles, } \\
\text { which cannot be } \\
\text { hand-picked can probably } \\
\text { not be recovered from the } \\
\text { silk material }\end{array}$ & $\begin{array}{l}\text { Reid et al. (2003) } \\
\text { and Thompson } \\
\text { et al. (2004) }\end{array}$ \\
\hline & Epibenthic sled & $\begin{array}{l}\text { A sled which is towed over the } \\
\text { sea bottom with a net placed at } \\
\text { a certain distance }(20 \mathrm{~cm}) \text { over } \\
\text { the bottom such that no } \\
\text { resuspended sediment is } \\
\text { collected }\end{array}$ & $\begin{array}{l}\text { large sample } \\
\text { volumesintegrates a high } \\
\text { area of water column }\end{array}$ & $\begin{array}{l}\text { high operation effort } \\
\text { obstacles on the ground } \\
\text { could block the net or } \\
\text { make the sample useless } \\
\text { due to resuspended } \\
\text { material } \\
\text { investigated size class is } \\
\text { limited through mesh size } \\
\text { contamination through } \\
\text { material of equipment }\end{array}$ & Lattin et al. (2004) \\
\hline
\end{tabular}




\section{Sample Preparation}

The environmental samples taken for MP analysis usually contain a high amount of biogenic material (biota and detritus) and inorganic material (clay, silicates). Therefore, extraction of MPs from the environmental matrix is crucial to facilitate the subsequent identification of MPs. Sometimes, sieving is used to remove larger particles ( $>5 \mathrm{~mm}$ ) from the samples as well as to divide them into distinct size fractions that might be further analyzed differently (Löder and Gerdts 2015). Especially for bulk sediment samples, MPs have to be extracted from the inorganic sediment matrix first while for water and biota samples the removal of the biogenic matrix is put first.

\section{Extraction Techniques}

Removing inorganic material from environmental samples is based on the fact that most MPs possess a considerably lower density (0.90-1.55 $\mathrm{g} \mathrm{cm}^{-3}$; Table 2) than the inorganic components of sediments like quartz sand or other silicates $\left(2.65 \mathrm{~g} \mathrm{~cm}^{-3}\right)$ (Hidalgo-Ruz et al. 2012). The most prominent extraction techniques are density separation or fluidization/ elutriation. According to Hanvey et al. (2017) density separation is by far the most prevalent one and is defined by the liquid used, the mixing time, the time for settling and the limits of subsequent size fractionation (Hanvey et al. 2017). The most common salt solution for separation is sodium chloride $(\mathrm{NaCl})$ with a density of $1.2 \mathrm{~g} / \mathrm{cm}^{3}$ (Thompson et al.
2004; Hidalgo-Ruz et al. 2012; Hanvey et al. 2017). Due to being inexpensive and non-hazardous, the use of $\mathrm{NaCl}$ is also recommended by Hanke et al. (2013), despite its relatively low density. By raising the density of the separation fluid, mainly by using other salt solutions, a better density gradient can be obtained (Filella 2015). These solutions include zinc chloride $\left(\mathrm{ZnCl}_{2}\right)$ with a density of $1.5-1.7 \mathrm{~g} \mathrm{~cm}^{-3}$ (Imhof et al. 2012; Imhof et al. 2013; Imhof et al. 2016; Mintenig et al. 2017), sodium iodide (NaI) with a density of $1.6 \mathrm{~g} \mathrm{~cm}^{-3}$ (Van Cauwenberghe et al. 2013a; Van Cauwenberghe et al. 2013b; Dekiff et al. 2014; Nuelle et al. 2014; Fischer and Scholz-Böttcher 2017), sodium polytungstate with a density of 1.4-1.5 $\mathrm{g} \mathrm{cm}^{-3}$ (Corcoran et al. 2009; Corcoran 2015), zinc bromide $\left(\mathrm{ZnBr}_{2}\right)$ with a density of $1.71 \mathrm{~g} \mathrm{~cm}^{-3}$ (Quinn et al. 2017) and calcium chloride $\left(\mathrm{CaCl}_{2}\right)$ with a density of 1.30-1.46 $\mathrm{g} \mathrm{cm}^{-3}$ (Stolte et al. 2015; Courtene-Jones et al. 2017). Samples are added to the separation fluid and either stirred or shaken for a defined time to separate MPs from the sediment matrix (Hanvey et al. 2017). These periods vary considerably between studies if indicated at all (Hidalgo-Ruz et al. 2012; Filella 2015; Hanvey et al. 2017). This is also true for settling times after mixing (Besley et al. 2017; Hanvey et al. 2017) which vary between several minutes (Nuelle et al. 2014; Corcoran 2015) and hours (Stolte et al. 2015; Imhof et al. 2016; Mintenig et al. 2017). Since the aim is to allow for all the sediment particles to sink and all MPs to rise through the whole fluid column according to their respective density, Besley et al. (2017) suggested a minimum settling time of 5-8 hours. Especially for small sample amounts, density separation can be done simply in a

Table 2 Density, heat deflection temperature (HDT), and chemical resistance of common plastic types (Osswald et al. 2006; Bürkle GmbH 2015; Qiu et al. 2016)

\begin{tabular}{|c|c|c|c|c|c|c|c|c|c|c|c|c|}
\hline \multirow[t]{3}{*}{ Plastic type } & \multirow{3}{*}{$\begin{array}{l}\text { Density } \rho \\
\mathrm{g} \mathrm{cm}^{-3}\end{array}$} & \multirow{3}{*}{$\begin{array}{l}\text { HDT } \\
{ }^{\circ} \mathrm{C} \\
\end{array}$} & \multicolumn{10}{|c|}{ Chemical resistance } \\
\hline & & & \multicolumn{2}{|c|}{$\mathrm{HCl}$} & \multirow{2}{*}{$\begin{array}{l}\mathrm{H}_{2} \mathrm{SO}_{4} \\
40 \%\end{array}$} & \multicolumn{2}{|l|}{$\mathrm{HNO}_{3}$} & \multicolumn{2}{|c|}{$\mathrm{NaOH}$} & \multirow{2}{*}{$\begin{array}{l}\mathrm{KOH} \\
10 \%\end{array}$} & \multirow{2}{*}{$\begin{array}{l}\mathrm{H}_{2} \mathrm{O}_{2} \\
30 \%\end{array}$} & \multirow{2}{*}{$\begin{array}{l}\mathrm{NaClO} \\
12.5 \% \\
\mathrm{Cl}\end{array}$} \\
\hline & & & $\begin{array}{l}5 \% \\
2 \mathrm{M}\end{array}$ & $\begin{array}{l}35 \% \\
11 \mathrm{M}\end{array}$ & & $5 \%$ & $66 \%$ & $\begin{array}{l}4 \% \\
1 \mathrm{M}\end{array}$ & $\begin{array}{l}30 \% \\
10 \mathrm{M}\end{array}$ & & & \\
\hline Acrylonitrile butadiene styrene (ABS) & $1.04-1.06$ & $95-105$ & - & - & - & - & - & - & - & - & - & - \\
\hline High-density polyethylene (HDPE) & $0.94-0.96$ & $\sim 50$ & $1 / 1$ & $1 / 1$ & $1 / 1$ & $1 / 1$ & $2 / 4$ & $1 / 1$ & $1 / 1$ & $1 / 1$ & $1 / 1$ & $2 / 3$ \\
\hline Low-density polyethylene (LDPE) & $0.91-0.92$ & $\sim 35$ & $1 / 1$ & $1 / 1$ & $1 / 1$ & $1 / 1$ & $3 / 4$ & $1 / 1$ & $1 / 1$ & $1 / 1$ & $1 / 2$ & $2 / 3$ \\
\hline Polyamide (PA) & $1.02-1.14$ & $55-120$ & $4 / 4$ & $4 / 4$ & $4 / 4$ & $4 / 4$ & $4 / 4$ & $1 /-$ & $1 /-$ & $1 /-$ & $4 / 4$ & $4 / 4$ \\
\hline Polybutylene terephthalate (PBT) & 1.31 & 60 & - & - & - & - & - & - & - & - & - & - \\
\hline Polycarbonate (PC) & 1.20 & $125-135$ & $1 / 1$ & $4 / 4$ & $2 /-$ & $1 / 2$ & $4 / 4$ & $3 / 4$ & $4 / 4$ & $4 / 4$ & $1 / 1$ & $2 / 3$ \\
\hline Polyethylene terephthalate (PET) & 1.37 & 80 & 2 & 4 & 4 & 2 & 4 & 3 & $4 / 4$ & $4 / 4$ & $1 /-$ & 3 \\
\hline Polymethyl methacrylate (PMMA) & $1.17-1.20$ & $75-105$ & - & - & - & - & - & - & - & - & - & - \\
\hline Polyoxymethylene (POM) & $1.41-1.42$ & $100-160$ & $4 / 4$ & $4 / 4$ & $4 / 4$ & $4 / 4$ & $4 / 4$ & $1 / 1$ & $1 / 3$ & $1 / 1$ & $4 / 4$ & $4 / 4$ \\
\hline Polypropylene (PP) & $0.90-0.91$ & $55-70$ & $1 / 1$ & $1 / 2$ & $1 / 1$ & $1 / 1$ & $4 / 4$ & $1 / 1$ & $1 / 1$ & $1 / 1$ & $1 / 3$ & $2 / 3$ \\
\hline Polystyrene (PS) & 1.05 & $65-85$ & $1 / 1$ & $3 / 3$ & $2 /-$ & $2 / 4$ & $4 / 4$ & $2 / 2$ & $1 /-$ & - & $1 / 2$ & $1 / 3$ \\
\hline Polysulfone (PSU) & 1.24 & $170-175$ & $1 / 1$ & $1 / 1$ & $3 /-$ & $1 / 3$ & $4 / 4$ & $1 / 1$ & $1 /-$ & - & $1 / 1$ & $1 / 1$ \\
\hline Polytetrafluoroethylene (PTFE) & $2.15-2.20$ & $50-60$ & $1 / 1$ & $1 / 1$ & $1 / 1$ & $1 / 1$ & $1 / 1$ & $1 / 1$ & $1 / 1$ & $1 / 1$ & $1 / 1$ & $1 / 1$ \\
\hline Polyurethane (PUR) & 1.05 & - & - & - & - & - & - & - & - & - & - & - \\
\hline Polyvinyl chloride (PVC) & $1.16-1.55$ & $65-75$ & $1 / 1$ & $2 / 3$ & $1 / 3$ & $1 / 2$ & $3 / 4$ & $1 / 1$ & $1 / 3$ & - & $1 / 1$ & $1 / 3$ \\
\hline Styrene acrylonitrile (SAN) & 1.08 & $95-100$ & $1 / 3$ & $1 / 3$ & $1 / 1$ & $1 / 3$ & - & - & - & - & $1 /-$ & $1 / 1$ \\
\hline
\end{tabular}

Chemical resistances are listed for temperatures of $+20^{\circ} \mathrm{C}$ (left digit and color code) and $+50{ }^{\circ} \mathrm{C}$ (right digit): $-=$ no data available, $1 /$ green $=$ resistant, $2 /$ yellow $=$ practically resistant, $3 /$ orange $=$ partially resistant, $4 / \mathrm{red}=$ not resistant 
beaker or flask where the supernatant is decanted or removed with a pipette or in a separatory funnel, where the inorganic material is removed via the bottom valve (Maes et al. 2017b; Mintenig et al. 2017; Zobkov and Esiukova 2017). Constructed devices like the Munich/MicroPlastic Sediment Separator (MPSS) by Imhof et al. (2012), designed for the extraction of MPs from large quantities of sediment (up to $6 \mathrm{~kg}$ ), and the small-scale Sediment-Microplastic Isolation (SMI) unit by Coppock et al. (2017) usually achieve very good recovery rates $(96 \%)$ even for small MPs $(<1 \mathrm{~mm}$; (Imhof et al. 2012), when applied with $\mathrm{ZnCl}_{2}$. According to Kedzierski et al. (2017), it is possible to extract $54 \%$ of the plastics produced in Europe with $\mathrm{NaCl}$ of $1.18 \mathrm{~g} \mathrm{~cm}^{-3}$ density while with a $1.8 \mathrm{~g} \mathrm{~cm}^{-3}$ solution (achievable with, e.g., $\mathrm{NaI}$, polytungstate, $\mathrm{ZnCl}_{2}$ ) the extraction of $93-98 \%$ is feasible. Therefore, achieved recovery rates are not only dependent on the device but mainly on the separation liquid used.

Another density based technique to separate MPs from sediment matrix is elutriation/fluidization, where water or air is pumped through the fluid column containing the sample and water or a salt solution (Claessens et al. 2013; Nuelle et al. 2014; Zhu 2015; Kedzierski et al. 2016). Recently, a non-density based extraction approach with canola oil has been developed by Crichton et al. (2017). The approach makes use of the oleophilic properties of MPs. So far it has only been tested with MPs larger than $500 \mu \mathrm{m}$, but showed high recovery rates of $96 \%$ (Crichton et al. 2017). When choosing one of the available methods, factors like sample volume or mass, time needed, costs, safety, toxicity, and extraction efficiency have to be considered.

For small amounts of sediment, approaches in flasks or funnels can be used or the novel developed SMI unit (Coppock et al. 2017; Maes et al. 2017b). If larger sediment volumes (1-6 L) are processed, elutriation systems or the MPSS would be a better choice (Imhof et al. 2012; Nuelle et al. 2014).

The time necessary for shaking should be adjusted to the sediment amount. The more sediment, the longer the mixing interval should be to assure that all MP particles are separated from the sediment particles. For settling, the span depends on the density gradient between MPs and liquid as well as the length of the fluidization column. Furthermore, the settling times have to be adjusted to the solutions used since particles rise and settle more slowly in more viscous solutions like $\mathrm{CaCl}_{2}$ or $\mathrm{ZnCl}_{2}$ (Crichton et al. 2017).

The most inexpensive approaches are simple setups with flasks and $\mathrm{NaCl}$ or oil. Zinc chloride is more expensive in relation to $\mathrm{NaCl}$, especially when adjusted to higher densities but by far less expensive than $\mathrm{NaI}$ and polytungstate (Coppock et al. 2017). At best, an effective and cost efficient setup is used with a high density solution that can be refurbished and that allows for a proper mixing of the sediment as well as a proper settling time.
Concentrated $\mathrm{NaCl}$ solutions as well as canola oil do not pose any hazard to the environment. Other salt solutions are more hazardous to health and the environment in ascending order: $\mathrm{NaI}, \mathrm{CaCl}_{2}$, polytungstate, $\mathrm{ZnCl}_{2}$. These solutions should therefore be recycled as far as possible due to financial and environmental reasons (Löder and Gerdts 2015). Kedzierski et al. (2017) showed that NaI can effectively be recycled without major density loss. Zinc chloride can be refurbished in large quantities quite easily via pressure filtration (Löder and Gerdts 2015). Miller et al. (2017) did an extensive comparison of different separation techniques on the basis of current literature and listed advantages and disadvantages. Based on this list, the authors recommended the use of $\mathrm{ZnBr}_{2}$ (Miller et al. 2017). Nevertheless, $\mathrm{ZnBr}_{2}$ has to date just been used by one study (Quinn et al. 2017) and $\mathrm{ZnCl}_{2}$ is not included in the list although it is suitable for the same density range, less expensive $\left(\mathrm{ZnBr}_{2}: 165 € \mathrm{~kg}^{-1}\right.$, $\mathrm{ZnCl}_{2}: 92.50 € \mathrm{~kg}^{-1}$, Merck Millipore, December 2017) and more widely used. Therefore, other authors have recommended the use of $\mathrm{ZnCl}_{2}$ as well (Löder and Gerdts 2015; Ivleva et al. 2016; Primpke et al. 2017a).

Independent of the extraction method chosen the next step is to filter the residual fluid or the supernatant of the (density) separation containing MPs to remove the respective salt solution and to concentrate the sample to certain size fractions.

\section{Sample Purification}

Before the samples can be analyzed the biogenic matter has to be removed. Sediment samples after density separation contain usually a relatively low amount of biogenic matter (benthic diatoms, copepods, polychaetes, bivalves, etc.). In contrast, samples from the sea surface, mostly taken with plankton nets, are normally very rich in biogenic matter (phyto- and zooplankton) as well as biota samples. The main digesting agents used for the removal of biogenic matter are acids like hydrochloric acid $(\mathrm{HCl})$, nitric acid $\left(\mathrm{HNO}_{3}\right)$ and sulphuric acid $\left(\mathrm{H}_{2} \mathrm{SO}_{4}\right)$ (Claessens et al. 2013; De Witte et al. 2014; Klein et al. 2015), bases like sodium hydroxide $(\mathrm{NaOH})$ and potassium hydroxide $(\mathrm{KOH})$ (Foekema et al. 2013; Dehaut et al. 2016; Karami et al. 2017; Wagner et al. 2017), oxidative agents like sodium hypochlorite $(\mathrm{NaClO})$ and hydrogen peroxide $\left(\mathrm{H}_{2} \mathrm{O}_{2}\right)$ (Nuelle et al. 2014; Avio et al. 2015; Collard et al. 2015; Tagg et al. 2017) and enzymes (Cole et al. 2014; Löder and Gerdts 2015; Courtene-Jones et al. 2017; Fischer and Scholz-Böttcher 2017; Mintenig et al. 2017). Several studies showed the destructive effects, i.e., discoloration, embrittlement or a loss in surface area, of acids (e.g., $\mathrm{HNO}_{3}$ ) and bases (e.g., $\mathrm{NaOH}$ ) on MPs especially at high temperatures (Cole et al. 2014; Nuelle et al. 2014; Bürkle GmbH 2015; Karami et al. 2017). Heat deflection 
temperatures of some plastics are around $50-80{ }^{\circ} \mathrm{C}$ or even below for PE (Osswald et al. 2006; Qiu et al. 2016). Therefore, it is generally recommended to use temperatures of less than $50^{\circ} \mathrm{C}$.

For $\mathrm{H}_{2} \mathrm{O}_{2}$, negative effects on synthetic polymers have been shown by Nuelle et al. (2014), but just after a weeklong treatment. The needed incubation time and effectiveness can be further improved by a new approach from Tagg et al. (2017) who used Fenton's reagent, a mixture of iron sulphate $\left(\mathrm{FeSO}_{4}\right)$ and $\mathrm{H}_{2} \mathrm{O}_{2}$. The digestion with enzymes is regarded to be non-destructive to MPs, targeting specifically proteins, polysaccharides and lipids. Cole et al. (2014) presented an approach with Proteinase-K and an up to $97.7 \%$ effective removal of biogenic matter. Courtene-Jones et al. (2017) digested mussel tissue with trypsin with an efficiency of $88 \%$. The biggest disadvantage of these treatments is the high cost of these specific enzymes. The succession of several technical enzymes in combination with sodium dodecyl sulphate (SDS) and an oxidative agent (i.e., $\mathrm{H}_{2} \mathrm{O}_{2}$ ) seems to be an effective, inexpensive, and non-hazardous alternative (Löder and Gerdts 2015; Löder et al. 2015; Fischer and Scholz-Böttcher 2017; Mintenig et al. 2017; Primpke et al. 2017b).

When choosing the most suitable digestion method several factors have to be considered: time, cost, destructiveness, and effectiveness.

Purification can take several minutes (Tagg et al. 2017), several hours (Cole et al. 2014; Dehaut et al. 2016) or several days (Foekema et al. 2013; Löder and Gerdts 2015; Karami et al. 2017). Generally, longer incubation times improve the effectiveness but might also negatively impact MPs. For example, Nuelle et al. (2014) showed a negative effect of a week-long treatment with $\mathrm{H}_{2} \mathrm{O}_{2}$ while no significant effect has been shown for shorter application periods (Nuelle et al. 2014; Tagg et al. 2017). Application time should be reduced to the maximum time before causing negative effects and to the minimum time necessary to cause the highest possible effectiveness.

Specific enzymes like Proteinase-K and trypsin are very expensive. Technical enzymes, on the other hand, can be used as an inexpensive alternative (Löder and Gerdts 2015; Löder et al. 2017; Mintenig et al. 2017).

It is noticeable that methods using acids are more destructive, especially at higher temperatures, than other methods. Only at low concentrations and low temperatures (5\%, $\left.25{ }^{\circ} \mathrm{C}\right) \mathrm{HCl}$ and $\mathrm{HNO}_{3}$ are less destructive than non-acid based methods, although they are also less effective at low temperatures and concentrations. For the alkaline treatments, $\mathrm{KOH}$ is more effective than $\mathrm{NaOH}$ with the same level of destructiveness. When comparing two oxidative treatments most frequently used, $\mathrm{H}_{2} \mathrm{O}_{2}$ is more effective than $\mathrm{NaClO}$ and less destructive.

Next to the potential destructiveness, the effectiveness of the treatment has to be taken into account when considering the most suitable digesting agent (Fig. 2). For most treatments, an increase in temperature provokes an increase in effectiveness but often also an increase in destructiveness. Some treatments might be very effective but also relatively destructive to $\mathrm{MPs}$ like $\mathrm{HNO}_{3}(69 \%)$ and $\mathrm{HCl}(37 \%)$ and other treatments are less destructive but also less effective like $\mathrm{NaOH}$ and $\mathrm{NaClO}$ (Karami et al. 2017). Enzymatic treatments represent the best choice in terms of being nondestructive to MPs. Several working groups have shown the high effectiveness of enzymatic digestion with different enzymes (Cole et al. 2014; Courtene-Jones et al. 2017; Karlsson et al. 2017; Löder et al. 2017; Mintenig et al. 2017).

\section{Microplastics Identification}

Once the environmental samples have been purified and concentrated by removing the biogenic and inorganic matter the MPs within the samples have to be identified. This identification is most easily performed by visual inspection either with the naked eye or with the use of a (stereo) microscope (Shim et al. 2017). The sorting is based on several criteria defined in a pilot-study by Norén (2007), which include having no visible cell-structure, homogenous coloration, and equal thickness for fibers (Enders et al. 2015). Nonetheless, Hidalgo-Ruz et al. (2012) stated that up to $70 \%$ of particles that potentially resembled MPs based on merely visual inspection could not be confirmed to be of synthetic origin. These limits of visual identification, even by experienced operators, have been shown by several studies (Eriksen et al. 2013; Dekiff et al. 2014; Lenz et al. 2015; Löder and Gerdts 2015; Song et al. 2015). Despite this high proneness to errors, many studies still rely on the visual identification of MPs. An overestimation can be avoided when a chemical characterization is subsequently performed to confirm plastics. If the chemical characterization is based on a prior visual sorting of potential MPs, an underestimation, especially of very small particles is still very likely (Song et al. 2015). Stains can be used to facilitate visual analysis, like Nile Red (Desforges et al. 2014; Shim et al. 2016; ErniCassola et al. 2017; Maes et al. 2017a) or rose bengal (Ivleva et al. 2016). Maes et al. (2017a) presented an approach using Nile Red that enabled for a reliable identification of MPs (96.6\% recovery for MPs of a 100-500 $\mu \mathrm{m}$ size range). Nevertheless, this approach does not allow for a differentiation of distinct polymer types (Maes et al. 2017a), and may only be suitable for identification of MPs used in organism studies, where the specific polymer type is known. For environmental samples, chemical characterization is needed and can be achieved by spectroscopic analyses like Fourier transform infrared (FTIR), Raman and energy dispersive X-ray (EDX) spectroscopy or thermal analysis (Ivleva et al. 2016; Shim et al. 2017). 


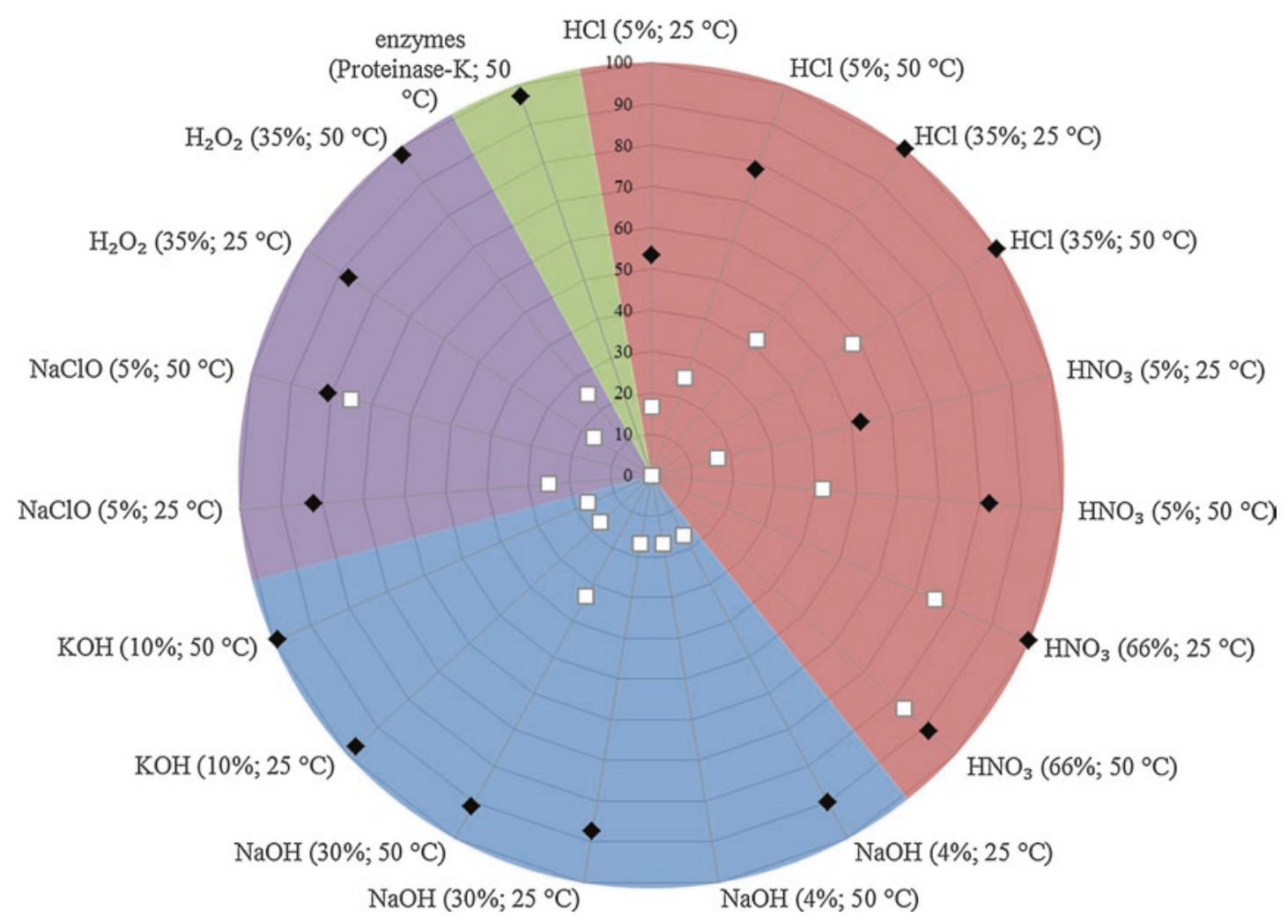

Fig. 2 Effectiveness of different digestion treatments (black symbols, in \%) and maximum percentage of microplastics negatively affected by the treatments (white symbols, based on 12 polymers). Different col-

ored sectors highlight the different treatments $=$ red: acid, blue $=$ alkaline, violet $=$ oxidative, green $=$ enzymatic (based on Cole et al. 2014; Bürkle GmbH 2015; Karami et al. 2017)

When combining EDX with scanning electron microscopy (SEM), this technique can provide information on the elemental composition of a particle and therefore distinguish plastics from inorganic materials (Eriksen et al. 2013; Vianello et al. 2013; Ivleva et al. 2016; Wagner et al. 2017; Wang et al. 2017). The identification of different plastic types is limited and therefore this method is recommended to be used for surface characterization and visualization additional to previous FTIR analysis (Vianello et al. 2013; Shim et al. 2017). FTIR analysis is a vibrational spectroscopic technique based on infrared radiation that excites molecular bonds resulting in vibrations that can be detected and transferred into characteristic absorbance spectra. These spectra can further be compared to a database of reference spectra allowing for the reliable identification of different polymer types. FTIR spectroscopy can be used in different modes, namely transmission (Löder et al. 2015; Käppler et al. 2016; Mintenig et al. 2017; Primpke et al. 2017b), reflection (Harrison et al. 2012; Vianello et al. 2013; Tagg et al. 2015) and attenuated total-reflectance (ATR) (Song et al. 2015; Käppler et al. 2016; Crichton et al. 2017; Imhof et al. 2017; Wagner et al. 2017). To measure very small particles FTIR spectroscopy can be coupled to microscopy $(\mu \mathrm{FTIR})$ and be used in all three modes as well (Ivleva et al. 2016; Shim et al. 2017). All these modes have several advantages and limita- tions. While the transmission mode provides high quality spectra it is restricted to a certain thickness of material to allow infrared radiation to pass through the sample without being fully absorbed (Löder and Gerdts 2015; Ivleva et al. 2016). Reflectance mode on the other hand provides spectra of thick and opaque particles but does depend on the surface properties since uneven surfaces can cause scattering effects which cause refractive errors (Löder and Gerdts 2015; Shim et al. 2017). High quality spectra can be achieved by $\mu$ ATRFTIR with the disadvantage of potentially damaging particles since a crystal has to be pressed on the sample (Ivleva et al. 2016; Shim et al. 2017). Another vibrational spectroscopy, that is complementary to FTIR, is Raman spectroscopy (Käppler et al. 2016). Monochromatic light, usually provided by a laser, irradiates the sample and vibrations are resulting in a Raman shift, which can be presented as substance characteristic spectra (Ivleva et al. 2016; Shim et al. 2017). Raman micro-spectrometry has successfully been used to identify MPs in environmental samples (Enders et al. 2015; Fischer et al. 2015; Frère et al. 2016; Imhof et al. 2016; Wagner et al. 2017). For thermal analysis, pyrolysis-gas chromatography-mass spectrometry (Pyr-GC-MS) and thermoextraction and desorption (TED) coupled with GC-MS are the most prevalent and promising ones (Fries et al. 2013; Dümichen et al. 2015; Fischer and Scholz-Böttcher 2017). 
Both methods provide the chemical composition based on heating the sample and analyzing the decomposition products (Ivleva et al. 2016). Pyrograms or ion chromatograms are obtained that can be compared to references, equivalent to spectra of spectroscopic techniques (Löder and Gerdts 2015; Dümichen et al. 2017; Shim et al. 2017).

Most studies use these methods to analyze preselected particles. Recently Fischer and Scholz-Böttcher (2017) presented also for Pyr-GC-MS an approach independent of a prior visual sorting by analysing whole filters on which previously purified samples had been concentrated. That also TED-GC-MS can be used to analyze subsamples of environmental samples without pre-selection to identify MPs has been shown by Dümichen et al. (2017). An advantage of TED-GC-MS presented by Dümichen et al. (2017) is that a relatively high sample amount of up to $100 \mathrm{mg}$ can be processed, which, depending on the condition of the environmental sample, obviates the need for sample purification.

Chemical imaging approaches developed for $\mu$ FTIR and Raman spectroscopy eliminate the need for a visual preselection. Therefore, the purified samples are concentrated on filters that are directly scanned. The filter chosen for the analysis has to be compatible to the method by not interfering with the sample analysis (Käppler et al. 2015; Löder et al. 2015). For $\mu$ FTIR the use of Focal plane array (FPA) detectors have substantially improved the time needed for the analysis of whole filter areas (Löder et al. 2015; Tagg et al. 2015; Käppler et al. 2016; Mintenig et al. 2017; Primpke et al. 2017b). Although the imaging using FPA is independent of a prior visual selection of potential MPs, the approach presented by Löder et al. (2015) still involves an operatorbased selection of MPs based on their spectral signature. Therefore, advances are automated approaches independent of human bias like it has been recently presented by Primpke et al. (2017b).

Shim et al. (2017) recently reviewed the advantages and disadvantages of currently used methods for identification of MPs. Furthermore, Elert et al. (2017) added to the comparison a classification of the different techniques in terms of restrictions, requirements and the analytical information received.

The major advantage of thermal analysis is the simultaneous analysis of polymer and containing additives, while the major disadvantage is the destruction of the sample by combustion. While thermal analyses provide mass-related results only, spectroscopic analyses are normally non-destructive and provide particle-related results (Shim et al. 2017). The lower size limit for $\mu$ FTIR is at $10 \mu \mathrm{m}$ due to the diffraction limit (Löder and Gerdts 2015; Shim et al. 2017), whereas for Raman spectroscopy particles down to $1 \mu \mathrm{m}$ size can be analyzed (Ivleva et al. 2016). Residual water hampers FTIR analysis while for Raman spectroscopy fluorescence of residues of the environmental matrix is a problem as well as the interference from pigments (Imhof et al. 2016; Käppler et al. 2016; Shim et al. 2017). Käppler et al. (2016) showed that Raman imaging provides a better identification of MPs $<20 \mu \mathrm{m}$ when compared to using FPA- $\mu$ FTIR in transmission mode but with the major drawback for Raman imaging that the measurement time was more than 100-times higher than the $\mu$ FTIR analysis. Currently, $\mu$ FTIR imaging of large filter areas is considerably faster than Raman imaging, even when reducing the resolution for Raman imaging, resulting in a comparable quality to FTIR imaging (Käppler et al. 2016).

All above mentioned methods share the commonality that to avoid misinterpretation of spectra and programs alike as well as identifying dyed MPs, efficient sample purification is of utmost importance (Löder and Gerdts 2015; Crichton et al. 2017; Fischer and Scholz-Böttcher 2017; Maes et al. 2017b). When choosing the most appropriate method: time demand, size range, and sample preparation have to be considered. Furthermore, thermal analysis should be used when a fast assessment of mass-related data is required, while spectroscopic analysis provides particle-related data but might take considerably longer. A holistic approach would involve FTIRanalysis of MPs down to $10 \mu \mathrm{m}$, Raman-analysis for MPs below $10 \mu \mathrm{m}$ and a subsequent thermal analysis.

\section{Biological Effects of Microplastics on Biota}

Although research on MPs in aquatic systems regarding monitoring and abundance in animals has dramatically increased in the last years, profound knowledge about the effects of MPs on biota is still scarce (Ribeiro et al. 2017). Here, we give a short overview about investigated consequences of MP exposure, methods, and their effects on organisms.

Images circulating the media of sea turtles, dolphins or seals entangled in plastic bags and other macroplastics are well known, but what about the plastic we do not see? Microplastics can pose a danger to organisms, when they are ingested (Avio et al. 2017). Reasons for ingestion in the first place are either MPs being mistaken for food or prey due to similarities in size, shape or color (Wright et al. 2013) or because the organism is not selective with food particles, which is, for example, the case for most filter and deposit feeders (Van Cauwenberghe et al. 2015). Although filter feeders often possess some mechanisms to avoid particles that are too big or inedible, MPs are very similar to actually nutritious food and thus sorting mechanisms might not work (Ward and Shumway 2004). 


\section{The Risk of Exposure to Microplastics}

When trying to assess the danger of MPs in the marine environment, various things have to be taken into consideration. The risk to be exposed to MPs varies a lot with compartments, usually divided into water surface, water column and sediments. Sediments are thought of as being the most affected compartment, because they function as a sink for MPs (Hidalgo-Ruz et al. 2012; Duis and Coors 2016). All compartments considerably vary spatially and temporally and distribution of MPs is, therefore, difficult to assess (Chubarenko et al. 2016).

Risk of exposure is different for the different types of polymers (buoyancy, fragmentation rate) and the habitat of the organism (surface layer, water column, sediment) (Andrady 2017). Polymers with low density tend to stay longer in the surface layer, possibly aggregating with phytoplankton in the euphotic zone (Long et al. 2017). They can also be overgrown by microbes and other fouling organisms and sink down in the water column together with MPs of neutral buoyancy. Higher density polymers such as polyvinyl chloride sink quickly and are readily available for benthic filter feeders or deposit feeders such as bivalves and polychaetes (Avio et al. 2017).

The hazard that MP poses for organisms also varies depending on the functional group such as the trophic level of the organism. So far, mainly low trophic levels such as filter feeders, deposit feeders and planktivorous fish have been found to be contaminated with MPs, but recently MP particles have also been detected in predatory pelagic fish such as tuna (Romeo et al. 2015) and even filter feeding mammals such as humpback whales (Besseling et al. 2015).

Studies have accumulated on examining fish guts for MPs and have found evidence of MPs among multiple species and life stages across different functional groups (Vendel et al. 2017). Transfer to higher trophic levels, such as fish preying on zooplankton that has ingested MPs, has been hypothesized but no clear evidence has been found yet (Santana et al. 2017). So far, studies give contradictory results with some claiming that MPs cascade to higher trophic levels (Setälä et al. 2014) while others disagree or argue that they travel to predators but do not persist in the gut (Santana et al. 2017).

\section{Effects Due to the Specific Properties of Microplastic Particles}

All types of MPs are hypothesized to cause gut blockage or a false sense of fullness, if not excreted within reasonable time span (Gall and Thompson 2015). Most MPs are socalled secondary MPs resulting from fragmentation of larger particles. Therefore, the shape of MPs can cause internal ruptures and injuries. Most studies have been conducted with primary MPs: spherical, highly defined microbeads not reflecting the situation in the environment, as the most commonly found types are fragments and fibers. This calls for the use of fragments or fibers in laboratory studies to enhance significance of the obtained results.

The effects of MPs on an organism depend a lot on its size. Seabirds often take up colorful plastic particles that fill up their stomach and can be too large for gut passage (van Franeker et al. 2011). Contrarily, very small particles (1-400 nm) (GESAMP 2015), called nanoplastics if $<100 \mathrm{~nm}$ (Löder and Gerdts 2015), can potentially be implemented in body cells after ingestion as they are small enough to pass pores in membranes. Inside the cell, the particles can potentially disturb other tissues than the digestive system such as the liver or lymph system (von Moos et al. 2012).

Impacts on biota can vary depending on the polymer type of the encountered MPs. Some polymers such as silicone are sturdier and break down slower under the influence of temperature and wave action than others due to their chemical composition. They fragment slower and are also less likely to leach pollutants as leaching of additives is dependent on surface area which increases with decreasing particle size (Suhrhoff and Scholz-Böttcher 2016). Other polymers, however, are already toxic in themselves by leaching monomers or oligomers such as polyvinyl chloride (PVC) or polystyrene (PS). These monomers have been shown to act as endocrine disruptors (Espinosa et al. 2016).

When MPs are introduced into the environment they are free of microorganisms and have not yet been impacted by waves or UV light. With time, MPs weather, pollutants adsorb and leach, and microorganisms start growing on the particles. These processes lead to changed characteristics of the MPs. With growing or adhering organisms the buoyancy changes and low density polymers start to sink and become available for a different range of organisms. Furthermore, biofilm-coated particles might not be recognizable anymore as MPs or seem more palatable due to chemical cues emitted from the microorganisms and are ingested with higher probability. Bacterial assemblages on MPs have also been found to be different from other surfaces with yet unknown consequences (Kesy et al. 2016).

Considering all of the above, there are various things to be accounted for when working with MP in the laboratory. Glass containers or glass material should be used as much as possible to reduce contamination sources. As this is only possible to a certain extent, negative controls should also account for plastic materials used within the experimental set-up. To assess the effects of MPs in experiments, the concentrations have to be determined, to which the organisms are exposed. Using spherical beads, this can be calculated via diameter, density and mass of the spheres. Irregular beads are more difficult to handle. Simple methods usually involve counting chambers (Syberg et al. 2015), light microscopy 
(Nobre et al. 2015) and quantitative filtering of the water samples. Other common methods are flow cytometer (Sussarellu et al. 2016) and the use of a coulter counter (Syberg et al. 2015). For characterization of the beads, FTIR (Lusher et al. 2017), Raman spectroscopy and electron microscopy (Murray and Cowie 2011) are the preferred methods. The next step is to determine the presence of MPs in the organism. This is usually achieved by dissecting to check for presence in gut systems or histological analysis of tissue samples (Farrell and Nelson 2013). Effects on the organism can be directly determined via deformations of larvae. Potentially, MPs can induce epigenetic effects, e.g., in copepods (Heindler et al. 2017). Epigenetics are usually viewed as a quick and advantageous mechanism for an F1 generation to adapt to a stressor to which the F0 generation was exposed. Microplastics can also cause a decrease in reproduction (Heindler et al. 2017) and are therefore directly affecting fitness. Sussarellu et al. (2016) also reported reductions in feeding activity, accumulation and inhibition of acetylcholinesterase activity in bivalves.

\section{Microplastics as Vector for Pollutants}

The effects of the combination of MPs with pollutants are ambivalently discussed. First, it is important to differentiate between pollutants adhering to plastics, which belong to the group of persistent organic pollutants (POPs), originating from the water, and between additives leaching from the MP particles or emittance of monomers or oligomers from the MPs themselves. The difference here is that pollutants that adhere to plastics are usually already widespread in the environment, while pollutants associated with plastic have only been around since the production of plastics, so roughly the 1950s (Hammer et al. 2012). Both groups of chemicals suggest a role of MPs as a vector to organisms. This is very debatable for pollutants already present in the environment as some argue that other pathways such as food and water are several magnitudes higher than the intake via MPs, simply due to the fact that MPs are still not that abundant in the ocean and, therefore, bioaccumulation of this POPs is not increased by MPs yet. Additionally, it is also discussed if leaching additives from MPs are of major concern. Here, it is important to differentiate between primary MPs and secondary MPs. Primary MPs are introduced already in the size range of MPs whereas secondary MPs are often introduced into the environment as macroplastics that fragment over time into MPs. They weather over time and it remains an open question how much additives are still present within those fragments.

Heindler et al. (2017) revealed in a study on the toxicity effects of polyethylene terephthalate (PET) and the common plasticizer diethylhexyl phthalate (DEHP) that copepod nau- plii are far more sensitive to exposure than adults. This stresses the need for assessing the toxicity of MPs at different life stages and focusing on juveniles or larvae, which are usually more sensitive to stressors than adults. Effects of MPs on younger life-stages can have knock-on effects on populations if for example mortality is significantly higher and fewer individuals reach sexual maturity and reproduce.

Regarding laboratory methods, again, glassware should be used where appropriate to make sure that no pollutant is adhered to the experimental container and, therefore, removed from the experiment. Toxin burdens can for example be assessed in different compartments (water, plastic, and biota) via high throughput liquid chromatography (HPLC) (Brennecke et al. 2015).

\section{Conclusion}

Although intensive research activities have already resolved some methodological issues in MP research, there are still some challenges, which need to be overcome before standardized operational protocols (SOPs) can be defined. Sampling effort (spatial and temporal replication, as well as sample volume) within a project is still limited by the high demand for personnel and physical resources as well as the long analysis time for MP samples. Thereby, an adequate sampling design should be chosen to answer pre-defined research questions as precisely as possible. It is obvious that different research questions require the use of different methods, which in turn will hamper complete standardization of methods. Nevertheless, a comprehensive and proper data recording, as well as gathering additional information, e.g., environmental data, will contribute to high quality datasets.

In addition, the extraction of MPs from environmental matrices is a crucial step, as inorganic and organic substances concurrently sampled with the potential MPs, can interfere with the subsequent analysis. Lately, many protocols have been proposed to remove inorganic or organic materials from samples. Thereby, developments were made to improve extraction efficiency, while not affecting fragile MPs, i.e., applying high density solutions for density separation of inorganic material or enzymatic purification of organic material. Finally, for a reliable identification of MPs a solely visible analysis is insufficient, and a chemical characterization is highly recommended. Spectroscopic methods like Ramanor FTIR-spectroscopy are state-of-the-art, providing particle related data (e.g., numbers, sizes) as well as thermal extraction methods like Pyr-GC-MS and TED-GC-MS, which provide mass related data and information about absorbed pollutants or contained additives.

Both methods will provide relevant information for further studies on the effects of MPs on organisms. There is still a huge lack of knowledge and besides evidence that MPs are 
ingested, either by mistake or because the organism is not selective in feeding, information about the effects is limited. The exposure to MPs will largely depend on the habitat of the organism (water surface, water column, sediment) and the feeding type (predatory, herbivory, planktivory). How the MPs affect the organism after ingestion is largely unknown but depends most likely very much on specific properties of the MPs (polymer type, size, shape) as well as life stage of the organism. The interaction of MPs with adsorbed pollutants seems to be negligible compared to already existing pathways (food, water), however, the effect of leaching additives is not yet determined. Thus, the effects of MPs on organisms still need intense research activities to come up with proper risk assessments for different life stages of different species to determine, who is most at risk and how to protect them.

\section{Appendix}

This article is related to the YOUMARES 8 conference session no. 13: "Microplastics in Aquatic Habitats -Environmental Concentrations and Consequences". The original Call for Abstracts and the abstracts of the presentations within this session can be found in the appendix "Conference Sessions and Abstracts", chapter "12 Microplastics in Aquatic Habitats Environmental Concentrations and Consequences", of this book.

\section{References}

Andrady AL (2017) The plastic in microplastics: a review. Mar Pollut Bull 119:12-22. https://doi.org/10.1016/j.marpolbul.2017.01.082

Avio CG, Gorbi S, Regoli F (2015) Experimental development of a new protocol for extraction and characterization of microplastics in fish tissues: first observations in commercial species from Adriatic Sea. Mar Environ Res 111:18-26. https://doi.org/10.1016/j. marenvres.2015.06.014

Avio CG, Gorbi S, Regoli F (2017) Plastics and microplastics in the oceans: from emerging pollutants to emerged threat. Mar Environ Res 128:2-11. https://doi.org/10.1016/j.marenvres.2016.05.012

Barrows APW, Neumann CA, Berger ML et al (2017) Grab vs. neuston tow net: a microplastic sampling performance comparison and possible advances in the field. Anal Methods 9:1446-1453. https://doi. org/10.1039/C6AY02387H

Bergmann M, Tekman MB, Gutow L (2017) LITTERBASE: an online portal for marine litter and microplastics and their implications for marine life. In: Baztan J, Jorgensen B, Pahl S et al (eds) Fate and impact of microplastics in marine ecosystems. Elsevier, MICRO 2016, Amsterdam, pp 106-107. https://doi.org/10.1016/ B978-0-12-812271-6.00104-6

Besley A, Vijver MG, Behrens P et al (2017) A standardized method for sampling and extraction methods for quantifying microplastics in beach sand. Mar Pollut Bull 114:77-83. https://doi.org/10.1016/j. marpolbul.2016.08.055

Besseling E, Foekema EM, Van Franeker JA et al (2015) Microplastic in a macro filter feeder: humpback whale Megaptera novaean- gliae. Mar Pollut Bull 95:248-252. https://doi.org/10.1016/j. marpolbul.2015.04.007

Brennecke D, Ferreira EC, Costa TMM et al (2015) Ingested microplastics $(>100 \mu \mathrm{m})$ are translocated to organs of the tropical fiddler crab Uca rapax. Mar Pollut Bull 96:491-495. https://doi.org/10.1016/j. marpolbul.2015.05.001

Browne MA, Chapman MG, Thompson RC et al (2015) Spatial and temporal patterns of stranded intertidal marine debris: is there a picture of global change? Environ Sci Technol 49:7082-7094. https:// doi.org/10.1021/es5060572

Bürkle GmbH (2015) Chemische Beständigkeit von Kunststoffen. Bürkle GmbH. URL:www.buerkle.de/files_pdf/wissenswertes/ chemical_resistance_en.pdf. Accessed 03 Aug 2017

Carson HS, Colbert SL, Kaylor MJ et al (2011) Small plastic debris changes water movement and heat transfer through beach sediments. Mar Pollut Bull 62:1708-1713. https://doi.org/10.1016/j. marpolbul.2011.05.032

Chae D-H, Kim I-S, Kim S-K et al (2015) Abundance and distribution characteristics of microplastics in surface seawaters of the Incheon/ Kyeonggi coastal region. Arch Environ Contam Toxicol 69:269278. https://doi.org/10.1007/s00244-015-0173-4

Chubarenko I, Bagaev A, Zobkov M et al (2016) On some physical and dynamical properties of microplastic particles in marine environment. Mar Pollut Bull 108:105-112. https://doi.org/10.1016/j. marpolbul.2016.04.048

Claessens M, Meester SD, Landuyt LV et al (2011) Occurrence and distribution of microplastics in marine sediments along the Belgian coast. Mar Pollut Bull 62:2199-2204. https://doi.org/10.1016/j. marpolbul.2011.06.030

Claessens M, Van Cauwenberghe L, Vandegehuchte MB et al (2013) New techniques for the detection of microplastics in sediments and field collected organisms. Mar Pollut Bull 70:227-233. https://doi. org/10.1016/j.marpolbul.2013.03.009

Cole M, Webb H, Lindeque PK et al (2014) Isolation of microplastics in biota-rich seawater samples and marine organisms. Sci Rep 4:4528. https://doi.org/10.1038/srep04528

Collard F, Gilbert B, Eppe G et al (2015) Detection of anthropogenic particles in fish stomachs: an isolation method adapted to identification by Raman spectroscopy. Arch Environ Contam Toxicol 69:331-339. https://doi.org/10.1007/s00244-015-0221-0

Connors KA, Dyer SD, Belanger SE (2017) Advancing the quality of environmental microplastic research. Environ Toxicol Chem 36:1697-1703. https://doi.org/10.1002/etc.3829

Coppock RL, Cole M, Lindeque PK et al (2017) A small-scale, portable method for extracting microplastics from marine sediments. Environ Pollut 230:829-837. https://doi.org/10.1016/j.envpol.2017.07.017

Corcoran PL (2015) Benthic plastic debris in marine and fresh water environments. Env Sci Process Impact 17:1363-1369. https://doi. org/10.1039/c5em00188a

Corcoran PL, Biesinger MC, Grifi M (2009) Plastics and beaches: a degrading relationship. Mar Pollut Bull 58:80-84. https://doi. org/10.1016/j.marpolbul.2008.08.022

Costa MF, Duarte AC (2017) Microplastics sampling and sample handling. Compr Anal Chem 75:25-47. https://doi.org/10.1016/ bs.coac.2016.11.002

Courtene-Jones W, Quinn B, Murphy F et al (2017) Optimisation of enzymatic digestion and validation of specimen preservation methods for the analysis of ingested microplastics. Anal Methods 9:1437-1445. https://doi.org/10.1039/C6AY02343F

Crichton EM, Noel M, Gies EA et al (2017) A novel, densityindependent and FTIR-compatible approach for the rapid extraction of microplastics from aquatic sediments. Anal Methods 9:14191428. https://doi.org/10.1039/C6AY02733D

De Witte B, Devriese L, Bekaert K et al (2014) Quality assessment of the blue mussel (Mytilus edulis): comparison between com- 
mercial and wild types. Mar Pollut Bull 85:146-155. https://doi org/10.1016/j.marpolbul.2014.06.006

Dehaut A, Cassone A-L, Frère L et al (2016) Microplastics in seafood: benchmark protocol for their extraction and characterization. Environ Pollut 215:223-233. https://doi.org/10.1016/j. envpol.2016.05.018

Dekiff JH, Remy D, Klasmeier J et al (2014) Occurrence and spatial distribution of microplastics in sediments from Norderney. Environ Pollut 186:248-256. https://doi.org/10.1016/j.envpol.2013.11.019

Desforges J-PW, Galbraith M, Dangerfield N et al (2014) Widespread distribution of microplastics in subsurface seawater in the NE Pacific Ocean. Mar Pollut Bull 79:94-99. https://doi.org/10.1016/j. marpolbul.2013.12.035

Doyle MJ, Watson W, Bowlin NM et al (2011) Plastic particles in coastal pelagic ecosystems of the Northeast Pacific Ocean. Mar Environ Res 71:41-52. https://doi.org/10.1016/j.marenvres.2010.10.001

Dubaish F, Liebezeit G (2013) Suspended microplastics and black carbon particles in the jade system, southern North Sea. Water Air Soil Pollut 224:1352-1359. https://doi.org/10.1007/s11270-012-1352-9

Duis K, Coors A (2016) Microplastics in the aquatic and terrestrial environment: sources (with a specific focus on personal care products), fate and effects. Environ Sci Eur 28:2

Dümichen E, Barthel A-K, Braun U et al (2015) Analysis of polyethylene microplastics in environmental samples, using a thermal decomposition method. Water Res 85:451-457. https://doi.org/10.1016/j. watres.2015.09.002

Dümichen E, Eisentraut P, Bannick CG et al (2017) Fast identification of microplastics in complex environmental samples by a thermal degradation method. Chemosphere 174:572-584. https://doi. org/10.1016/j.chemosphere.2017.02.010

Edson EC, Patterson MR (2015) MantaRay: a novel autonomous sampling instrument for in situ measurements of environmental microplastic particle concentrations. Paper presented at the OCEANS 2015 - MTS/IEEE Washington, DC, pp 19-22 Oct 2015

Elert AM, Becker R, Duemichen E et al (2017) Comparison of different methods for MP detection: what can we learn from them, and why asking the right question before measurements matters? Environ Pollut 231:1256-1264. https://doi.org/10.1016/j. envpol.2017.08.074

Enders K, Lenz R, Stedmon CA et al (2015) Abundance, size and polymer composition of marine microplastics $\geq 10 \mu \mathrm{m}$ in the Atlantic Ocean and their modelled vertical distribution. Mar Pollut Bull 100:70-81. https://doi.org/10.1016/j.marpolbul.2015.09.027

Eriksen M, Mason S, Wilson S et al (2013) Microplastic pollution in the surface waters of the Laurentian Great Lakes. Mar Pollut Bull 77:177-182. https://doi.org/10.1016/j.marpolbul.2013.10.007

Erni-Cassola G, Gibson MI, Thompson RC et al (2017) Lost, but found with Nile red: a novel method for detecting and quantifying small microplastics $(1 \mathrm{~mm}$ to $20 \mu \mathrm{m})$ in environmental samples. Environ Sci Technol. https://doi.org/10.1021/acs.est.7b04512

Espinosa C, Esteban MÁ, Cuesta A (2016) Microplastics in aquatic environments and their toxicological implications for fish. In: Soloneski S, Larramendy ML (eds) Toxicology - new aspects to this scientific conundrum. InTech, Rijeka, pp 113-145. https://doi. org/10.5772/64815

Farrell P, Nelson K (2013) Trophic level transfer of microplastic: Mytilus edulis (L.) to Carcinus maenas (L.). Environ Pollut 177:13. https://doi.org/10.1016/j.envpol.2013.01.046

Filella M (2015) Questions of size and numbers in environmental research on microplastics: methodological and conceptual aspects. Environ Chem 12:527-538. https://doi.org/10.1071/EN15012

Fischer M, Scholz-Böttcher BM (2017) Simultaneous trace identification and quantification of common types of microplastics in environmental samples by pyrolysis-gas chromatography-mass spectrometry. Environ Sci Technol 51:5052-5060. https://doi. org/10.1021/acs.est.6b06362
Fischer D, Kaeppler A, Eichhorn K-J (2015) Identification of microplastics in the marine environment by Raman microspectroscopy and imaging. Am Lab 47:32-34

Fisner M, Majer AP, Balthazar-Silva D et al (2017) Quantifying microplastic pollution on sandy beaches: the conundrum of large sample variability and spatial heterogeneity. Environ Sci Pollut Res 24:13732-13740. https://doi.org/10.1007/s11356-017-8883-y

Foekema EM, De Gruijter C, Mergia MT et al (2013) Plastic in North Sea fish. Environ Sci Technol 47:8818-8824. https://doi. org/10.1021/es400931b

Frère L, Paul-Pont I, Moreau J et al (2016) A semi-automated Raman micro-spectroscopy method for morphological and chemical characterizations of microplastic litter. Mar Pollut Bull 113:461-468. https://doi.org/10.1016/j.marpolbul.2016.10.051

Fries E, Dekiff JH, Willmeyer J et al (2013) Identification of polymer types and additives in marine microplastic particles using pyrolysis-GC/MS and scanning electron microscopy. Environ Sci Processes Impact 15:1949-1956. https://doi.org/10.1039/ C3EM00214D

Gall SC, Thompson RC (2015) The impact of debris on marine life. Mar Pollut Bull 92:170-179. https://doi.org/10.1016/j. marpolbul.2014.12.041

GESAMP (2015) Sources, fate and effects of microplastics in the marine environment: a global assessment. In: Kershaw PJ (ed) (IMO/FAO/UNESCO-IOC/UNIDO/WMO/IAEA/UN/UNEP/ UNDP Joint Group of Experts on the Scientific Aspects of Marine Environmental Protection). Rep. Stud. GESAMP No. 90

GESAMP (2016) Sources, fate and effects of microplastics in the marine environment: part two of a global assessment. In: Kershaw PJ, Rochmann CM (eds) (IMO/FAO/UNESCO-IOC/UNIDO/ WMO/IAEA/UN/UNEP/UNDP Joint Group of Experts on the Scientific Aspects of Marine Environmental Protection). Rep. Stud. GESAMP No. 93

Goldstein MC, Titmus AJ, Ford M (2013) Scales of spatial heterogeneity of plastic marine debris in the Northeast Pacific Ocean. PLoS One 8:e80020. https://doi.org/10.1371/journal.pone.0080020

Hammer J, Kraak MHS, Parsons JR (2012) Plastics in the marine environment: the dark side of a modern gift. In: Whitacre DM (ed) Reviews of environmental contamination and toxicology, vol 220. Springer, New York, pp 1-44. https://doi.org/10.1007/978-1-4614-3414-6_1

Hanke G, Galgani F, Werner S et al (2013) MSFD GES technical subgroup on marine litter. Guidance on Monitoring of marine litter in European Seas European Commission. https://doi. org/10.2788/99475

Hanvey JS, Lewis PJ, Lavers JL et al (2017) A review of analytical techniques for quantifying microplastics in sediments. Anal Methods 9:1369-1383. https://doi.org/10.1039/C6AY02707E

Harrison JP, Ojeda JJ, Romero-González ME (2012) The applicability of reflectance micro-Fourier-transform infrared spectroscopy for the detection of synthetic microplastics in marine sediments. Sci Total Environ 416:455-463. https://doi.org/10.1016/j. scitotenv.2011.11.078

Heindler FM, Alajmi F, Huerlimann R et al (2017) Toxic effects of polyethylene terephthalate microparticles and $\mathrm{Di}$ (2-ethylhexyl) phthalate on the calanoid copepod, Parvocalanus crassirostris. Ecotoxicol Environ Saf 141:298-305. https://doi.org/10.1016/j. ecoenv.2017.03.029

Heo N, Hong S, Han G et al (2013) Distribution of small plastic debris in cross-section and high strandline on Heungnam beach, South Korea. Ocean Sci J 48:225-233. https://doi.org/10.1007/ s12601-013-0019-9

Hidalgo-Ruz V, Gutow L, Thompson RC, Thiel M (2012) Microplastics in the marine environment: a review of the methods used for identification and quantification. Environ Sci Technol 46:3060-3075. https://doi.org/10.1021/es2031505 
Imhof HK, Schmid J, Niessner R et al (2012) A novel, highly efficient method for the separation and quantification of plastic particles in sediments of aquatic environments. Limnol Oceanogr Methods 10:524-537. https://doi.org/10.4319/lom.2012.10.524

Imhof HK, Ivleva NP, Schmid J et al (2013) Contamination of beach sediments of a subalpine lake with microplastic particles. Curr Biol 23:R867-R868

Imhof HK, Laforsch C, Wiesheu AC et al (2016) Pigments and plastic in limnetic ecosystems: a qualitative and quantitative study on microparticles of different size classes. Water Res 98:64-74. https://doi. org/10.1016/j.watres.2016.03.015

Imhof HK, Sigl R, Brauer E et al (2017) Spatial and temporal variation of macro-, meso- and microplastic abundance on a remote coral island of the Maldives, Indian Ocean. Mar Pollut Bull 116:340-347. https://doi.org/10.1016/j.marpolbul.2017.01.010

Ivleva NP, Wiesheu AC, Niessner R (2016) Microplastic in aquatic ecosystems. Angew Chem Int Ed 56:1720-1739. https://doi. org/10.1002/anie.201606957

Kang J-H, Kwon OY, Lee K-W et al (2015) Marine neustonic microplastics around the southeastern coast of Korea. Mar Pollut Bull 96:304-312. https://doi.org/10.1016/j.marpolbul.2015.04.054

Käppler A, Windrich F, Löder MJ et al (2015) Identification of microplastics by FTIR and Raman microscopy: a novel silicon filter substrate opens the important spectral range below $1300 \mathrm{~cm}^{-1}$ for FTIR transmission measurements. Anal Bioanal Chem 407:6791-6801. https://doi.org/10.1007/s00216-015-8850-8

Käppler A, Fischer D, Oberbeckmann S et al (2016) Analysis of environmental microplastics by vibrational microspectroscopy: FTIR, Raman or both? Anal Bioanal Chem 408:8377-8391. https://doi. org/10.1007/s00216-016-9956-3

Karami A, Golieskardi A, Choo CK et al (2017) A high-performance protocol for extraction of microplastics in fish. Sci Total Environ 578:485-494. https://doi.org/10.1016/j.scitotenv.2016.10.213

Karlsson TM, Vethaak AD, Almroth BC et al (2017) Screening for microplastics in sediment, water, marine invertebrates and fish: method development and microplastic accumulation. Mar Pollut Bull 122:403-408. https://doi.org/10.1016/j.marpolbul.2017.06.081

Kedzierski M, Le Tilly V, Bourseau P et al (2016) Microplastics elutriation from sandy sediments: a granulometric approach. Mar Pollut Bull 107:315-323. https://doi.org/10.1016/j. marpolbul.2016.03.041

Kedzierski M, Le Tilly V, César G et al (2017) Efficient microplastics extraction from sand. A cost effective methodology based on sodium iodide recycling. Mar Pollut Bull 115:120-129. https://doi. org/10.1016/j.marpolbul.2016.12.002

Kesy K, Oberbeckmann S, Müller F et al (2016) Polystyrene influences bacterial assemblages in Arenicola marina-populated aquatic environments in vitro. Environ Pollut 219:219-227. https://doi. org/10.1016/j.envpol.2016.10.032

Kim I-S, Chae D-H, Kim S-K et al (2015) Factors influencing the spatial variation of microplastics on high-tidal coastal beaches in Korea. Arch Environ Contam Toxicol 69:299-309. https://doi.org/10.1007/ s00244-015-0155-6

Klein S, Worch E, Knepper TP (2015) Occurrence and spatial distribution of microplastics in river shore sediments of the Rhine-main area in Germany. Environ Sci Technol 49:6070-6076. https://doi. org/10.1021/acs.est.5b00492

Lattin GL, Moore CJ, Zellers AF et al (2004) A comparison of neustonic plastic and zooplankton at different depths near the southern California shore. Mar Pollut Bull 49:291-294. https://doi. org/10.1016/j.marpolbul.2004.01.020

Law KL, Morét-Ferguson S, Maximenko NA et al (2010) Plastic accumulation in the North Atlantic subtropical gyre. Science 329:11851188. https://doi.org/10.1126/science.1192321

Law KL, Morét-Ferguson SE, Goodwin DS et al (2014) Distribution of surface plastic debris in the eastern Pacific Ocean from an 11-year data set. Environ Sci Technol 48:4732-4738. https://doi. org/10.1021/es4053076

Lenz R, Enders K, Stedmon CA (2015) A critical assessment of visual identification of marine microplastic using Raman spectroscopy for analysis improvement. Mar Pollut Bull 100:82-91. https://doi. org/10.1016/j.marpolbul.2015.09.026

Löder MGJ, Gerdts G (2015) Methodology used for the detection and identification of microplastics-a critical appraisal. In: Bergmann M, Gutow L, Klages M (eds) Marine anthropogenic litter. Springer, Cham, pp 201-227. https://doi.org/10.1007/978-3-319-16510-3_8

Löder MGJ, Kuczera M, Mintenig S et al (2015) Focal plane array detector-based micro-Fourier-transform infrared imaging for the analysis of microplastics in environmental samples. Environ Chem 12:563-581. https://doi.org/10.1071/EN14205

Löder MGJ, Imhof HK, Ladehoff M et al (2017) Enzymatic purification of microplastics in environmental samples. Environ Sci Technol. https://doi.org/10.1021/acs.est.7b03055

Long M, Paul-Pont I, Hégaret $\mathrm{H}$ et al (2017) Interactions between polystyrene microplastics and marine phytoplankton lead to speciesspecific hetero-aggregation. Environ Pollut 228:454-463. https:// doi.org/10.1016/j.envpol.2017.05.047

Lusher AL, Burke A, O'Connor I et al (2014) Microplastic pollution in the Northeast Atlantic Ocean: validated and opportunistic sampling. Mar Pollut Bull 88:325-333. https://doi.org/10.1016/j. marpolbul.2014.08.023

Lusher AL, Welden NA, Sobral P et al (2017) Sampling, isolating and identifying microplastics ingested by fish and invertebrates. Anal Methods 9:1346-1360. https://doi.org/10.1039/C6AY02415G

Maes T, Jessop R, Wellner N et al (2017a) A rapid-screening approach to detect and quantify microplastics based on fluorescent tagging with Nile Red. Sci Rep 7:44501. https://doi.org/10.1038/srep44501

Maes T, Van der Meulen MD, Devriese LI et al (2017b) Microplastics baseline surveys at the water surface and in sediments of the north-East Atlantic. Front Mar Sci 4:135. https://doi.org/10.3389/ fmars.2017.00135

Masura J, Baker J, Foster G et al (2015) Laboratory methods for the analysis of microplastics in the marine environment: recommendations for quantifying synthetic particles in waters and sediments. NOAA Technical Memorandum, Silver Spring

Miller ME, Kroon FJ, Motti CA (2017) Recovering microplastics from marine samples: a review of current practices. Mar Pollut Bull 123:6-18. https://doi.org/10.1016/j.marpolbul.2017.08.058

Mintenig SM, Int-Veen I, Löder MGJ et al (2017) Identification of microplastic in effluents of waste water treatment plants using focal plane array-based micro-Fourier-transform infrared imaging. Water Res 108:365-372. https://doi.org/10.1016/j.watres.2016.11.015

Moreira FT, Prantoni AL, Martini B et al (2016) Small-scale temporal and spatial variability in the abundance of plastic pellets on sandy beaches: methodological considerations for estimating the input of microplastics. Mar Pollut Bull 102:114-121. https://doi. org/10.1016/j.marpolbul.2015.11.051

Murray F, Cowie PR (2011) Plastic contamination in the decapod crustacean Nephrops norvegicus (Linnaeus, 1758). Mar Pollut Bull 62:1207-1217. https://doi.org/10.1016/j.marpolbul.2011.03.032

Ng KL, Obbard JP (2006) Prevalence of microplastics in Singapore's coastal marine environment. Mar Pollut Bull 52:761-767. https:// doi.org/10.1016/j.marpolbul.2005.11.017

Nobre CR, Santana MFM, Maluf A et al (2015) Assessment of microplastic toxicity to embryonic development of the sea urchin Lytechinus variegatus (Echinodermata: Echinoidea). Mar Pollut Bull 92:99-104. https://doi.org/10.1016/j.marpolbul.2014.12.050

Norén F (2007) Small plastic particles in Coastal Swedish waters. KIMO Sweden, Lysekil

Nuelle M-T, Dekiff JH, Remy D et al (2014) A new analytical approach for monitoring microplastics in marine sediments. Environ Pollut 184:161-169. https://doi.org/10.1016/j.envpol.2013.07.027 
Obbard RW, Sadri S, Wong YQ et al (2014) Global warming releases microplastic legacy frozen in Arctic Sea ice. Earth's Future 2:315320. https://doi.org/10.1002/2014EF000240

Osswald TA, Baur E, Brinkmann S et al (2006) International plastics handbook. Hanser, München

Primpke S, Imhof H, Piehl S et al (2017a) Mikroplastik in der Umwelt. Chem unserer Zeit 51:402-412. https://doi.org/10.1002/ ciuz.201700821

Primpke S, Lorenz C, Rascher-Friesenhausen R et al (2017b) An automated approach for microplastics analysis using focal plane array (FPA) FTIR microscopy and image analysis. Anal Methods 9:1499_ 1511. https://doi.org/10.1039/C6AY02476A

Qiu Q, Tan Z, Wang J et al (2016) Extraction, enumeration and identification methods for monitoring microplastics in the environment. Estuar Coast Shelf Sci 176:102-109. https://doi.org/10.1016/j. ecss.2016.04.012

Quinn B, Murphy F, Ewins C (2017) Validation of density separation for the rapid recovery of microplastics from sediment. Anal Methods 9:1491-1498. https://doi.org/10.1039/C6AY02542K

Reid PC, Colebrook JM, Matthews JBL et al (2003) The Continuous Plankton Recorder: concepts and history, from Plankton Indicator to undulating recorders. Prog Oceanogr 58:117-173. https://doi. org/10.1016/j.pocean.2003.08.002

Reisser J, Slat B, Noble K et al (2015) The vertical distribution of buoyant plastics at sea: an observational study in the North Atlantic Gyre. Biogeosciences 12:1249-1256. https://doi.org/10.5194/ bg-12-1249-2015

Ribeiro F, Garcia AR, Pereira BP et al (2017) Microplastics effects in Scrobicularia plana. Mar Pollut Bull 122:379-391. https://doi. org/10.1016/j.marpolbul.2017.06.078

Romeo T, Pietro B, Pedà C et al (2015) First evidence of presence of plastic debris in stomach of large pelagic fish in the Mediterranean Sea. Mar Pollut Bull 95:358-361. https://doi.org/10.1016/j. marpolbul.2015.04.048

Santana MFM, Moreira FT, Turra A (2017) Trophic transference of microplastics under a low exposure scenario: insights on the likelihood of particle cascading along marine food-webs. Mar Pollut Bull 121:154-159. https://doi.org/10.1016/j.marpolbul.2017.05.061

Setälä O, Fleming-Lehtinen V, Lehtiniemi M (2014) Ingestion and transfer of microplastics in the planktonic food web. Environ Pollut 185:77-83. https://doi.org/10.1016/j.envpol.2013.10.013

Setälä O, Magnusson K, Lehtiniemi M et al (2016) Distribution and abundance of surface water microlitter in the Baltic Sea: a comparison of two sampling methods. Mar Pollut Bull 110:177-183. https:// doi.org/10.1016/j.marpolbul.2016.06.065

Shim WJ, Song YK, Hong SH et al (2016) Identification and quantification of microplastics using Nile Red staining. Mar Pollut Bull 113:469-476. https://doi.org/10.1016/j.marpolbul.2016.10.049

Shim WJ, Hong SH, Eo SE (2017) Identification methods in microplastic analysis: a review. Anal Methods 9:1384-1391. https://doi. org/10.1039/C6AY02558G

Song YK, Hong SH, Jang M et al (2014) Large accumulation of micro-sized synthetic polymer particles in the sea surface microlayer. Environ Sci Technol 48:9014-9021. https://doi.org/10.1021/ es501757s

Song YK, Hong SH, Jang M et al (2015) A comparison of microscopic and spectroscopic identification methods for analysis of microplastics in environmental samples. Mar Pollut Bull 93:202-209. https:// doi.org/10.1016/j.marpolbul.2015.01.015

Stolte A, Forster S, Gerdts G et al (2015) Microplastic concentrations in beach sediments along the German Baltic coast. Mar Pollut Bull 99:216-229. https://doi.org/10.1016/j.marpolbul.2015.07.022

Suhrhoff TJ, Scholz-Böttcher BM (2016) Qualitative impact of salinity, UV radiation and turbulence on leaching of organic plastic additives from four common plastics - a lab experiment. Mar Pollut Bull 102:84-94. https://doi.org/10.1016/j.marpolbul.2015.11.054
Sussarellu R, Suquet M, Thomas Y et al (2016) Oyster reproduction is affected by exposure to polystyrene microplastics. Proc Natl Acad Sci U S A 113:2430-2435. https://doi.org/10.1073/ pnas. 1519019113

Syberg K, Khan FR, Selck H et al (2015) Microplastics: addressing ecological risk through lessons learned. Environ Toxicol Chem 34:945-953. https://doi.org/10.1002/etc.2914

Tagg AS, Sapp M, Harrison JP et al (2015) Identification and quantification of microplastics in wastewater using focal plane arraybased reflectance micro-FT-IR imaging. Anal Chem 87:6032-6040. https://doi.org/10.1021/acs.analchem.5b00495

Tagg AS, Harrison JP, Ju-Nam Y et al (2017) Fenton's reagent for the rapid and efficient isolation of microplastics from wastewater. Chem Commun 53:372-375. https://doi.org/10.1039/C6CC08798A

Thompson RC, Olsen Y, Mitchell RP et al (2004) Lost at sea: where is all the plastic? Science 304:838. https://doi.org/10.1126/ science. 1094559

Turra A, Manzano AB, Dias RJS et al (2014) Three-dimensional distribution of plastic pellets in sandy beaches: shifting paradigms. Sci Rep 4:4435. https://doi.org/10.1038/srep04435

Underwood AJ, Chapman MG, Browne MA (2017) Some problems and practicalities in design and interpretation of samples of microplastic waste. Anal Methods 9:1332-1345. https://doi.org/10.1039/ C6AY02641A

Van Cauwenberghe L, Claessens M, Vandegehuchte $\mathrm{MB}$ et al (2013a) Assessment of marine debris on the Belgian Continental Shelf. Mar Pollut Bull 73:161-169. https://doi.org/10.1016/j. marpolbul.2013.05.026

Van Cauwenberghe L, Vanreusel A, Mees J et al (2013b) Microplastic pollution in deep-sea sediments. Environ Pollut 182:495-499. https://doi.org/10.1016/j.envpol.2013.08.013

Van Cauwenberghe L, Claessens M, Vandegehuchte MB et al (2015) Microplastics are taken up by mussels (Mytilus edulis) and lugworms (Arenicola marina) living in natural habitats. Environ Pollut 199:10-17. https://doi.org/10.1016/j.envpol.2015.01.008

van Franeker JA, Blaize C, Danielsen J et al (2011) Monitoring plastic ingestion by the northern fulmar Fulmarus glacialis in the North Sea. Environ Pollut 159:2609-2615. https://doi.org/10.1016/j. envpol.2011.06.008

Vendel AL, Bessa F, Alves VEN et al (2017) Widespread microplastic ingestion by fish assemblages in tropical estuaries subjected to anthropogenic pressures. Mar Pollut Bull 117:448-455. https://doi. org/10.1016/j.marpolbul.2017.01.081

Vianello A, Boldrin A, Guerriero P et al (2013) Microplastic particles in sediments of lagoon of Venice, Italy: first observations on occurrence, spatial patterns and identification. Estuar Coast Shelf Sci 130:54-61. https://doi.org/10.1016/j.ecss.2013.03.022

Viršek MK, Palatinus A, Koren Š et al (2016) Protocol for microplastics sampling on the sea surface and sample analysis. J Vis Exp 118:55161. https://doi.org/10.3791/55161

von Moos N, Burkhardt-Holm P, Kohler A (2012) Uptake and effects of microplastics on cells and tissue of the blue mussel Mytilus edulis L. after an experimental exposure. Environ Sci Technol 46:1132711335. https://doi.org/10.1021/es302332w

Wagner J, Wang Z-M, Ghosal S et al (2017) Novel method for the extraction and identification of microplastics in ocean trawl and fish gut matrices. Anal Methods 9:1479-1490. https://doi.org/10.1039/ C6AY02396G

Wang Z-M, Wagner J, Ghosal S et al (2017) SEM/EDS and optical microscopy analyses of microplastics in ocean trawl and fish guts. Sci Total Environ 603:616-626. https://doi.org/10.1016/j. scitotenv.2017.06.047

Ward EJ, Shumway SE (2004) Separating the grain from the chaff: particle selection in suspension- and deposit-feeding bivalves. J Exp Mar Biol Ecol 300:83-130. https://doi.org/10.1016/j.jembe.2004.03.002 
Woodall LC, Sanchez-Vidal A, Canals M et al (2014) The deep sea is a major sink for microplastic debris. R Soc open Sci 1:140317. https://doi.org/10.1098/rsos.140317

Wright SL, Thompson RC, Galloway TS (2013) The physical impacts of microplastics on marine organisms: a review. Environ Pollut 178:483-492. https://doi.org/10.1016/j.envpol.2013.02.031

Zhao S, Danley M, Ward JE et al (2017) An approach for extraction, characterization and quantitation of microplastic in natural marine snow using Raman microscopy. Anal Methods 9:1470-1478. https://doi.org/10.1039/C6AY02302A

Zhu X (2015) Optimization of elutriation device for filtration of microplastic particles from sediment. Mar Pollut Bull 92:69-72. https:// doi.org/10.1016/j.marpolbul.2014.12.054

Zobkov M, Esiukova E (2017) Microplastics in Baltic bottom sediments: quantification procedures and first results. Mar Pollut Bull 114:724-732. https://doi.org/10.1016/j.marpolbul.2016.10.060
Open Access This chapter is licensed under the terms of the Creative Commons Attribution 4.0 International License (http://creativecommons.org/licenses/by/4.0/), which permits use, sharing, adaptation, distribution and reproduction in any medium or format, as long as you give appropriate credit to the original author(s) and the source, provide a link to the Creative Commons license and indicate if changes were made.
The images or other third party material in this chapter are included in the chapter's Creative Commons license, unless indicated otherwise in a credit line to the material. If material is not included in the chapter's Creative Commons license and your intended use is not permitted by statutory regulation or exceeds the permitted use, you will need to obtain permission directly from the copyright holder. 